\title{
Echoes of the crises in Spain and US in the Colombian labor market: a differences-in-differences approach
}

\author{
Luis E. Arango ${ }^{1}$ - Dolores de la Mata ${ }^{2}$. \\ Nataly Obando ${ }^{3}$
}

Received: 11 October 2011 / Accepted: 19 August 2015 / Published online: 19 September 2015 (C) The Author(s) 2015. This article is published with open access at Springerlink.com

\begin{abstract}
This paper presents evidence of the effect of the recent phases of the business cycle in Spain and United States, proxied by their respective unemployment rates, on the labor market of Colombian cities with high migration tradition. These countries are the main destination for Colombian labor migrants. By using information from the household survey between 2006 and 2011 for urban areas in Colombia and a differences-in-differences approach, we find that unemployment rates of those countries negatively affect the probability of receiving remittances and the amount received by Colombian households living in areas with high and moderate migration tradition. In a second stage, we provide evidence that unemployment rates of those countries positively affect labor force participation decisions in Colombian regions with the highest migration tradition.
\end{abstract}

The opinions expressed here are not necessarily neither of Banco de la República, its Board of Directors, nor IADB nor CAF. We appreciate comments, suggestions and corrections of the Editor of the Journal and an anonymous referee. We also acknowledge useful insights by Juan Esteban Carranza. Research assistance of Gabriela Bonilla and Álvaro José Pinzón is greatly acknowledged. Usual disclaimers apply.

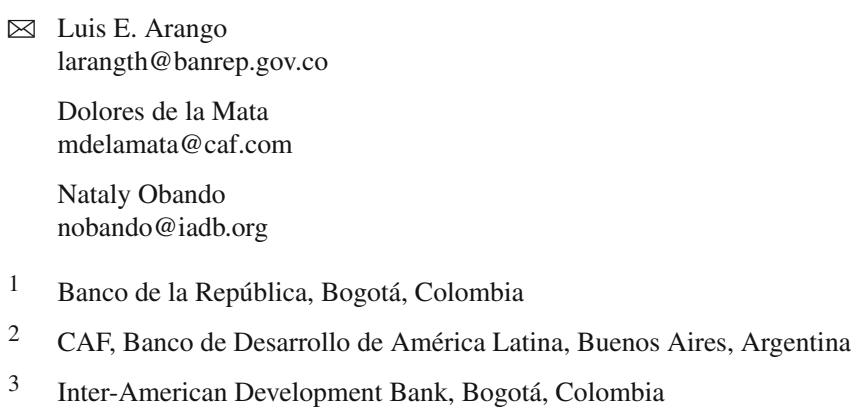


Keywords Migration - Remittances - Labor participation - Spanish and United States unemployment rates

JEL Classification $\mathrm{C} 21 \cdot \mathrm{J} 21 \cdot \mathrm{J} 22$

\section{Introduction}

International labor mobility affects economies in a myriad of dimensions. Considering the migrants' country of origin, migration affects labor supply composition in terms of human capital and skills, wages in local markets, asset accumulation, exchange rate movements, and reception of remittances. The latter are potential determinants of schooling and labor market decisions of non-migrants ( Fajnzylber and López 2008; Medina and Cardona 2010; Cárdenas et al. 2010).

The causes and effects of migration and remittances on labor force participation of non-migrants can be difficult to identify as has been recognized previously in the literature (see for example, Hanson 2007; Amuedo-Dorantes and Pozo 2010). First, remittances could increase non-migrants reservation wages, making it more difficult to accept any offer in the labor market as well as discouraging them to keep searching for a job when the search period is longer than expected. Second, migration itself, irrespective of the presence of remittances, can affect the labor-leisure decisions of secondary workers in the household, given that some of them may have to take the place of the migrant to compensate the income she previously provided. Third, if migration is massive in the city or region, secondary workers could engage in market activities given the increase in the real wage due to the contraction of labor supply. Thus, at the end, the effects of migration and remittances can compensate or mitigate each other.

The results found by previous literature in this regard are mixed. Funkhouser (1992), for Nicaragua, and Kim (2007), for Jamaica, show that remittances reduced labor force participation (see also Bussolo and Medvedev 2007). Hanson (2007) and Cox-Edwards and Rodriguez-Oreggia (2009) study the link between remittances and labor market participation for the case of Mexico. The first study finds that women in states of highmigration rates are less likely to work outside the home. According to Cox-Edwards and Rodriguez-Oreggia (2009), remittances have only a marginal effect on the whole labor force participation and a larger one on women participation, specifically in urban areas of states with relatively low migration tradition. More recently, Arango et al. (2013), show that in Colombia reception of remittances is associated with a lower probability of participation in the labor market, mainly in zones of high migration tradition such as Pereira. Mora (2013) also analyzed the case of Colombia finding that the participation decision is affected negatively by remittances. Finally, Bargain and Boutin (2014) find that child labor market activities in Burkina Faso are reduced as a result of remittances.

Colombia offers an interesting scenario where it is possible to evaluate the causal effects of migration and remittances on non-migrants' labor force participation decisions using a quasi-experimental empirical design. Two key aspects are the regional heterogeneity of emigration rates and the highly focalized destinations of Colombian 
migrants, Spain and the United States. Interestingly, while economic conditions in Spain and US were worsening after 2008, labor force participation rates in areas with high migration tradition in Colombia experienced a rapid increase, relative to other areas, leading to a notable increase in unemployment rates. Recent research (Cárdenas et al. 2010; Arango et al. 2013) pointed out the dynamics of remittances as a potential determinant of the changing labor force participation rates in areas with high migration tradition.

The purpose of this paper is threefold. The first objective is to study whether economic conditions in the two countries which are the main destinations of Colombian immigrants, Spain and US, affect the flow of remittances to households in the high migration areas. The second objective-provided the effect on remittances is present-is to identify the causal effect of economic conditions in foreign countries on non-migrants' labor force participation. Finally, given that during an important fraction of the sample period the economic conditions of the main Colombian migrants host countries worsened, we also explore whether part of the effects on labor force participation could be driven by returning migrants.

In order to identify such causal effects we implement a differences-in-differences (DD) approach which exploits two sources of variation: the heterogeneity of emigration rates across Colombian regions and the changes in unemployment rates, as proxy for economic conditions, during the period 2006:10-2011:12 in Spain and US. These two sources of variation generate exogenous changes in the flow of remittances across the Colombian regions.

The data we use correspond to the Great Integrated Household Survey (GEIH is the Spanish acronym). Additionally, we use the Colombian 2005 census data to classify municipalities in the GEIH as areas with high or low emigration rates. This regional variation allows us to construct treatment and control groups. The treatment groups are individuals residing in Colombian municipalities with high migration rates, which are more likely to be exposed and affected by the changing economic conditions of immigrants' host countries. Specifically in these groups, more than $5 \%$ of the households have at least one family member living in either Spain or US. We further divide the treatment in two to consider different intensity of the treatment. ${ }^{1}$ The control group consists of individuals residing in municipalities with very low emigration rates-with less than $2 \%$ of the households with at least one family member living in Spain or the United States-which is less likely to be affected by the changing economic conditions in foreign countries. ${ }^{2}$

Our results indicate that an increase in the unemployment rate of foreign countries (Spain or the US) reduces both the probability that a household in the treatment groups

\footnotetext{
${ }^{1}$ According to the Ministry of Foreign Affairs, Pereira, which is classified as a treatment municipality, is one of the cities with the highest experience in international migration in the country. About $14.5 \%$ of households have at least one member living abroad and of those, $77 \%$ are located in Spain. This information, borrowed from the "Survey data on international migration and remittances in the West Central Metropolitan Area" (AMCO 2010) and conducted by Departamento Administrativo Nacional de Estadística, DANE (the Official Statistics Bureau) in July 2004, suggests that remittances from abroad represent $10 \%$ of total household income.

2 Municipalities with a low proportion of households with at least one family member living in Spain or US (between 2 and $5 \%$ ) are left out of the baseline analysis, but used lately for a placebo analysis.
} 
receives remittances and the amount of remittances. The results also indicate that the worsening of the economic conditions in foreign countries increases labor force participation in municipalities with high emigration rates, relative to municipalities with moderate emigration rates. This evidence is consistent with the theoretical prediction that lower remittances increase the probability of engagement in labor market activities through their income effect. ${ }^{3}$ We do not find any results on household size, indicating that any effect we find on the labor force participation decisions should be driven mainly by remittances sent by migrants.

We implement several robustness exercises to validate our results. First, we perform placebo regressions where we use treatment group individuals residing in municipalities with relatively low emigration rates as placebo, which should not be affected by changes in external economic conditions. We show that, as expected, there are no effects of the unemployment rates of Spain or US on labor force participation decisions of individuals in the placebo treatment group. Second, we show that our results are not sensitive to the definition of the control group. Third, given that our empirical strategy relies on the assumption that the increase in unemployment rates in the principal host countries of Colombian immigrants was unexpected for Colombian households we shorten the period of analysis in which this assumption is more likely to hold and we find similar results. Finally, we carry out an exercise in which the sample is restricted to individuals of households who did not receive remittances in the 12 months prior to the interview. These individuals are less likely to be affected by changes in external economic conditions and we show that, indeed, the effects are lower for this subgroup.

This paper contributes to empirical literature linking migration and remittances with non-migrant labor force participation decisions, with a novel differences-indifferences empirical strategy. Specifically, we identify causal effects of the economic conditions of the main Colombian migrant's destination countries on reception of remittances and labor force participation decisions by exploiting regional heterogeneity in emigration rates as well as the worsening economic conditions experimented by those countries in the period 2006-2011. This empirical strategy is in the spirit of Amuedo-Dorantes and Pozo (2010) and Fajardo et al. (2014), who exploit variability in unemployment rates where the migrant resides (across US regions) to analyze household decisions at origin. Their empirical strategy is much more data demanding than ours, since they require detailed information about residence of the emigrated family member, which is not always available in household surveys, like the GEIH.

Previous research on the link between remittances and labor market participation in Colombia has been carried out (see for example, Cárdenas et al. 2010; Garay and Rodríguez 2005; Cadena and Cárdenas 2004; Mora 2013; Arango et al. 2013). However, our contributions go in different ways such as the explicit discussion of

\footnotetext{
3 One question that arises, but is beyond of the scope of this article, is one related to the educational level of migrants and the vulnerability of their occupations to the business cycle. It is possible that Spain and the United States are presenting a negative selection of immigrants (see Borjas 2000, chapter 9; Medina and Posso 2009) and Colombian workers in these countries are the first to be fired during the crises. Our results suggest that migrants from Pereira could be affected by this aspect due to the level of education in the city.
} 
endogeneity associated to remittances receipt and a clear empirical strategy to address it. $^{4}$

The article is organized as follows. The Sect. 2 reviews some facts about migration, remittances and labor market in cities of high, moderately-high, low and very low migration tradition. The Sect. 3 presents the data. The Sect. 4 explains the empirical strategy to test the hypothesis that labor participation in Colombia is sensitive, in a differential fashion among the cities, to the Spanish and United States business cycle through remittances and the effect of the return of some migrants. The Sect. 5 shows and discusses the results. The Sect. 6 presents robustness analysis. Finally, the Sect. 7 concludes.

\section{Migration, remittances and labor market facts}

\subsection{Migration and remittances}

Table 1 presents Census 2005 data of the proportion of households with at least one family member living abroad for each of the Colombian municipalities that conforms the domain named "thirteen areas", which comprises the thirteen major cities and their metropolitan areas. ${ }^{5}$ The table highlights two important facts about Colombian migration: first, that there is substantial cross-regions variation, and second, that migration is highly concentrated in two main destinations: Spain and the United States.

We classify the municipalities in Table 1 into four groups, according to the migration rate to Spain and the United States. A first group with municipalities with the highest emigration rates, conformed by Pereira, Dosquebradas and La Virginia (Group 1); a second set composed of cities of moderately-high migration rates such as Cali, Yumbo and Envigado (Group 2). The rest of municipalities (those with migration rates below $5 \%$ ) are divided into two groups: Group 3 comprises the cities with low migration rates such as Itagüí, Manizales, Sabaneta, etc. (with migration rates between 2 and $5 \%$ ), and Group 4 is composed of cities with very low migration rates (below $2 \%$ ). Figure 1 shows the location of all these municipalities in Colombia.

Figure 2 shows the proportion of households that reported receiving remittances in the period 2006-2011, according to the GEIH, and clarifies the relevance of this source of income for families from Groups 1 and $2 .^{6}$ The figure also shows the decrease in the share of households receiving remittances in municipalities of Group 1 after July 2008, which goes from 19.7 to $12.5 \%$ in October 2009. By the end of 2011, the proportion of family beneficiaries was about $16 \%$. This decrease is not so clear in municipalities of Group 2.

\footnotetext{
4 In order to deal with endogeneity of remittances, Mora (2013) uses the Internet access of families assuming that this variable is correlated to remittances, but not with labor participation.

5 Table 1 reports information only for municipalities in the GEIH survey which we use later for the empirical analysis.

6 As we mention below, between 2009 and 2011 remittances represented 14, 12 and 10\%, respectively, of GDP of Risaralda the province whose capital city is Pereira. For Valle del Cauca, the province whose capital city is Cali, remittances represented $5 \% ; 4$ and $4 \%$ during the same years (source, Banco de la República).
} 
Table 1 Proportion of families with at least one family member living abroad

\begin{tabular}{|c|c|c|c|c|c|c|}
\hline & \multirow{2}{*}{$\begin{array}{l}\text { Population } \\
2005 \text { census }\end{array}$} & \multicolumn{5}{|c|}{ Proportion of households with relatives in } \\
\hline & & $\begin{array}{l}\text { All } \\
\text { destinations } \\
(\%)\end{array}$ & $\begin{array}{l}\text { Spain } \\
(\%)\end{array}$ & $\begin{array}{l}\text { North } \\
\text { America } \\
(\%)\end{array}$ & $\begin{array}{l}\text { Centro } \\
\text { and South } \\
\text { America } \\
(\%)\end{array}$ & $\begin{array}{l}\text { Spain and } \\
\text { United } \\
\text { States }(\%)\end{array}$ \\
\hline \multicolumn{7}{|l|}{ Group 1} \\
\hline Dosquebradas & 179,282 & 13.10 & 7.20 & 3.89 & 0.75 & 10.95 \\
\hline Pereira & 443,442 & 11.63 & 5.73 & 4.10 & 0.61 & 9.66 \\
\hline La Virginia & 31,266 & 7.83 & 4.29 & 1.55 & 0.62 & 5.82 \\
\hline \multicolumn{7}{|l|}{ Group 2} \\
\hline Cali & $2,119,843$ & 7.37 & 2.40 & 3.17 & 0.74 & 5.39 \\
\hline Yumbo & 92,214 & 6.74 & 0.85 & 4.66 & 0.47 & 5.35 \\
\hline Envigado & 174,150 & 7.32 & 3.34 & 2.10 & 0.87 & 5.20 \\
\hline \multicolumn{7}{|l|}{ Group 3} \\
\hline Itagüí & 234,973 & 5.00 & 0.84 & 3.23 & 0.46 & 3.88 \\
\hline Manizales & 379,794 & 5.20 & 1.76 & 2.20 & 0.57 & 3.77 \\
\hline Sabaneta & 44,443 & 4.78 & 0.78 & 3.08 & 0.41 & 3.65 \\
\hline Villamaría & 46,324 & 4.39 & 0.77 & 2.48 & 0.51 & 3.13 \\
\hline Medellín & $2,214,494$ & 4.24 & 2.01 & 1.23 & 0.50 & 3.09 \\
\hline Copacabana & 61,230 & 3.53 & 1.34 & 1.48 & 0.38 & 2.78 \\
\hline Barranquilla & $1,146,498$ & 4.61 & 0.38 & 2.03 & 1.57 & 2.28 \\
\hline Bello & 371,625 & 3.18 & 0.73 & 1.66 & 0.46 & 2.28 \\
\hline Bucaramanga & 516,460 & 3.80 & 0.79 & 1.41 & 0.90 & 1.98 \\
\hline \multicolumn{7}{|l|}{ Group 4} \\
\hline La Estrella & 25,571 & 2.61 & 0.39 & 1.56 & 0.33 & 1.84 \\
\hline Caldas & 968,586 & 2.90 & 0.40 & 1.51 & 0.32 & 1.74 \\
\hline Bogotá, D. C. & $6,840,116$ & 2.38 & 0.69 & 1.09 & 0.31 & 1.73 \\
\hline Girardota & 42,581 & 2.90 & 0.78 & 0.77 & 0.84 & 1.43 \\
\hline Floridablanca & 254,600 & 2.05 & 0.55 & 0.94 & 0.28 & 1.42 \\
\hline Ibagué & 498,130 & 2.43 & 0.70 & 0.79 & 0.43 & 1.38 \\
\hline Barbosa & 42,453 & 1.57 & 0.45 & 0.78 & 0.22 & 1.22 \\
\hline Cartagena & 893,033 & 2.98 & 0.21 & 0.90 & 1.36 & 1.02 \\
\hline Piedecuesta & 117,405 & 2.98 & 0.21 & 0.90 & 1.36 & 0.99 \\
\hline Villavicencio & 380,328 & 1.82 & 0.39 & 0.67 & 0.40 & 0.90 \\
\hline Girón & 135,860 & 2.41 & 0.52 & 0.53 & 0.97 & 0.71 \\
\hline Soledad & 461,603 & 1.61 & 0.45 & 0.32 & 0.61 & 0.65 \\
\hline Cúcuta & 587,567 & 3.09 & 0.23 & 0.37 & 2.28 & 0.52 \\
\hline Pasto & 382,422 & 1.34 & 0.22 & 0.36 & 0.49 & 0.49 \\
\hline Villa del Rosario & 69,484 & 3.35 & 0.24 & 0.21 & 2.73 & 0.39 \\
\hline
\end{tabular}


Table 1 continued

\begin{tabular}{lclllll}
\hline & $\begin{array}{l}\text { Population } \\
2005 \text { census }\end{array}$ & \multicolumn{2}{l}{ Proportion of households with relatives in } \\
\cline { 3 - 6 } & & $\begin{array}{l}\text { All } \\
\text { destinations } \\
(\%)\end{array}$ & $\begin{array}{l}\text { Spain } \\
(\%)\end{array}$ & $\begin{array}{l}\text { North } \\
\text { America } \\
(\%)\end{array}$ & $\begin{array}{l}\text { Centro } \\
\text { and South } \\
\text { America } \\
(\%)\end{array}$ & $\begin{array}{l}\text { Spain } \\
\text { United } \\
\text { States }(\%)\end{array}$ \\
\hline Los Patios & 67,239 & 2.82 & 0.19 & 0.22 & 2.19 & 0.37 \\
Montería & 379,794 & 0.96 & 0.15 & 0.24 & 0.44 & 0.35 \\
El Zulia & 20,309 & 0.61 & 0.04 & 0.00 & 0.56 & 0.04 \\
\hline
\end{tabular}

Source: Census, 2005; authors' calculations

Remittances are an important income source for households in Pereira and are even considered by them as a "quasi-permanent income" (Garay and Rodríguez 2005) 7 and they are mainly used for food $(29.3 \%)$, utilities $(23.3 \%)$ and housing $(15.5 \%) .^{8}$ According to Cadena and Cárdenas (2004), remittances have been used to afford basic needs (food, education, housing, etc.) and are an alternative income during the recession phases of the Colombian cycle. $.^{9}, 10$

Table 2 characterizes households in each group of municipalities, separately for those receiving remittances and those that do not. Families receiving remittances are more likely to be led by females, their heads are older, have on average fewer children, and also have higher income relative to those not receiving remittances. All this would suggest that remittances are an endogenous variable, making it difficult to extract simple conclusions about the causal effect of remittances on labor force participation just by comparing these two groups.

Comparing characteristics across groups of municipalities, we see that households in municipalities with higher migration rates have, on average, lower educated heads, lower income and, in most cases, lower family size. These differences may account for part of the differences in labor force participation across regions and should be controlled for in our empirical specifications.

\subsection{Labor force participation}

Figure 3 shows the labor participation rate of each group of municipalities together with the proportion of households that receive remittances and the unemployment rate

\footnotetext{
7 Sánchez (2008) analyzes aspects related to remittances and poverty.

${ }^{8}$ Medina and Cardona (2010) found that beneficiaries of remittances spend about $10 \%$ more of their total spending on education.

${ }^{9}$ In this sense, the authors suggest that remittances were countercyclical and served the purpose of smoothing consumption. However, it is possible that during the 2008 crisis the countercyclical behavior of remittances has switched to a pro-cyclical behavior.

10 In the case of Mexican immigrants with work experience in the United States, Amuedo-Dorantes and Pozo (2006) claim that remittances are used as an insurance mechanism which takes two forms: familyprovided insurance and self-insurance, the latter linked to asset accumulation in Mexico.
} 


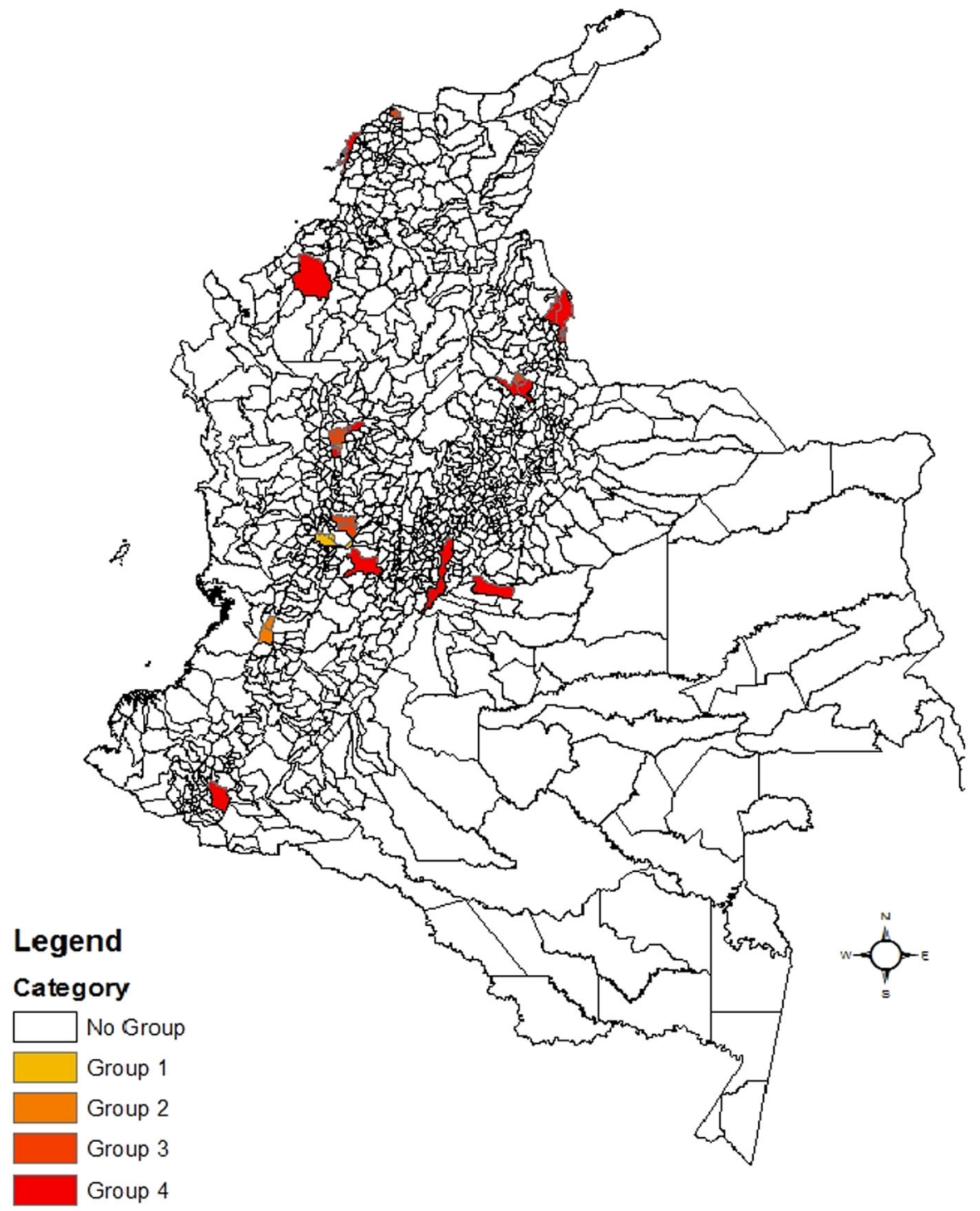

Fig. 1 Geographic localization of cities by migration rates in Colombia. Source: Census, 2005

of Spain and US. From the picture we can observe that participation (solid lines) started to rise at the beginning of 2007 in municipalities of Groups 2, 3 and 4, while it started about one year later in municipalities of Group 1. Movements in the participation rate of this group are fairly close to the decrease in the proportion of households receiving remittances. This phenomenon could have at least two possible explanations. First, it could be driven by the reduction in remittances received by the households in Group 1 , as a consequence of the worsening economic conditions in the main destination countries of Colombian emigrants. Note that participation rates in municipalities of 




Fig. 2 Proportion of households that received remittances per group of cities. Source: DANE: GEIH; authors' calculations

Group 4-where remittances have a low incidence-do not present an increase as sharp as in Group 1. Second, it could be explained by the return of migrants from Spain and US as a consequence of the crisis.

Garay and Rodríguez (2005) argue that remittances reduce the incentives to participate in the labor market by increasing the reservation wage for secondary workers; however, they do not verify this statement at all. More recently, Cárdenas et al. (2010) find that, on the one hand, remittances do not have a significant effect on labor force participation of males living in households with an absent migrant, but, on the other, individuals in households receiving remittances are almost $4 \%$ less likely to participate in the labor market.

To provide further evidence that the labor participation differences across groups are not just due to different trends, Fig. 4 presents these rates but for a longer period of time (2001-2011), linking the GEIH survey with the previous Colombian household survey, Encuesta Continua de Hogares (ECH). The figure shows that although participation rates increased in the period 2007-2011, this was not a long run trend. Additionally, it shows that Group 1 did not experience such a different behavior relative to the others in the period 2001-2006.

\section{Data}

We use the GEIH for the period November 2006 to December 2011. ${ }^{11}$ The GEIH is a nationally representative monthly cross-section survey, interviewing about 248,028 households annually, both in urban and rural areas. The questionnaires ask about housing conditions, demographic characteristics, occupation and working conditions,

\footnotetext{
11 The GEIH Survey started in July 2006. Given that there were some implementation issues during the first months, we prefer to discard the first three waves from our sample.
} 
Table 2 Some characteristics of families by migration rate tradition. 2007-2011

\begin{tabular}{|c|c|c|c|c|}
\hline Characteristic & $\begin{array}{l}\text { Group 1: high } \\
\text { migration rate }\end{array}$ & $\begin{array}{l}\text { Group 2: moderate } \\
\text { migration rate }\end{array}$ & $\begin{array}{l}\text { Group 3: } \\
\text { intermediate } \\
\text { migration rate }\end{array}$ & $\begin{array}{l}\text { Group 4: low } \\
\text { migration rate }\end{array}$ \\
\hline \multicolumn{5}{|l|}{ Receptors of remittances } \\
\hline $\begin{array}{l}\text { Proportion female } \\
\text { headed household } \\
(\%)\end{array}$ & 53.7 & 49.8 & 54.0 & 54.0 \\
\hline $\begin{array}{l}\text { Proportion male } \\
\text { headed household } \\
(\%)\end{array}$ & 46.3 & 50.2 & 46.0 & 46.0 \\
\hline $\begin{array}{l}\text { Average age of the } \\
\text { head }\end{array}$ & 50.9 & 51.0 & 52.9 & 51.1 \\
\hline $\begin{array}{l}\text { Education of the } \\
\text { head }\end{array}$ & 8.1 & 8.9 & 9.4 & 9.8 \\
\hline Size of family & 3.4 & 3.7 & 3.5 & 3.5 \\
\hline Number of children & 0.30 & 0.33 & 0.28 & 0.34 \\
\hline $\begin{array}{l}\text { Average family } \\
\text { income }\end{array}$ & $1,461,924$ & $1,531,459$ & $1,871,273$ & $1,943,780$ \\
\hline $\begin{array}{l}\text { Average family } \\
\text { remittances }\end{array}$ & 474,253 & 299,906 & 414,196 & 382,038 \\
\hline \multicolumn{5}{|c|}{ Non-receptors of remittances } \\
\hline $\begin{array}{l}\text { Proportion female } \\
\text { headed household } \\
(\%)\end{array}$ & 36.8 & 34.7 & 35.3 & 32.6 \\
\hline $\begin{array}{l}\text { Proportion male } \\
\text { headed household } \\
(\%)\end{array}$ & 63.2 & 65.3 & 64.7 & 67.4 \\
\hline $\begin{array}{l}\text { Average age of the } \\
\text { head }\end{array}$ & 47.8 & 46.9 & 48.4 & 46.4 \\
\hline $\begin{array}{l}\text { Education of the } \\
\text { head }\end{array}$ & 8.1 & 8.8 & 8.9 & 9.3 \\
\hline Size of family & 3.4 & 3.4 & 3.6 & 3.7 \\
\hline Number of children & 0.36 & 0.37 & 0.37 & 0.41 \\
\hline $\begin{array}{l}\text { Average family } \\
\text { income }\end{array}$ & $1,267,168$ & $1,407,138$ & $1,533,438$ & $1,629,340$ \\
\hline
\end{tabular}

Averages family income and remittances are in real terms $(2011: 12=100)$. Source: DANE: GEIH; authors' calculations

schooling, income sources (among which there are remittances), certain types of social benefits, among others.

The first outcomes of interest at the household level are whether any member of it receives remittances and the total amount. Specifically, the survey asks information about remittances received by each household member in the last 12 months. Accordingly, we construct two variables: first, a dummy variable that takes the value of one if the household received remittances in the last 12 months; second, a variable with the total amount of remittances (nominal Colombian pesos) received in the last 12 months by all household members. Unfortunately, the survey does not collect direct infor- 

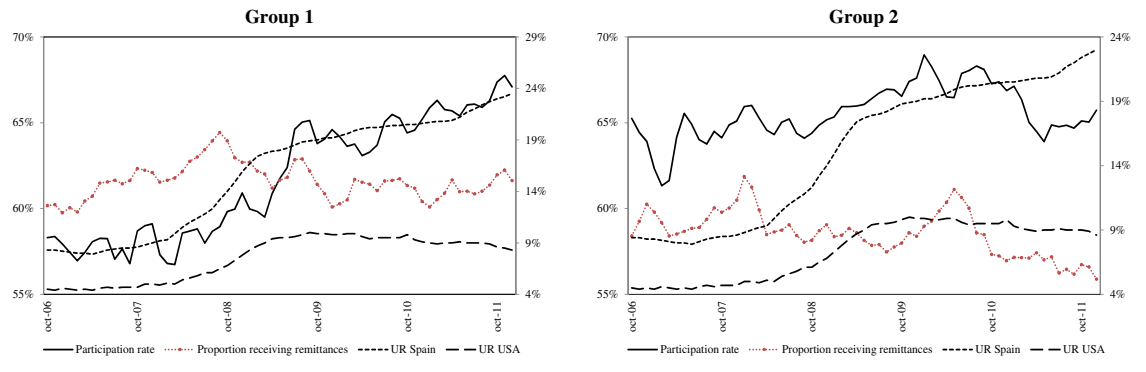

Group 3
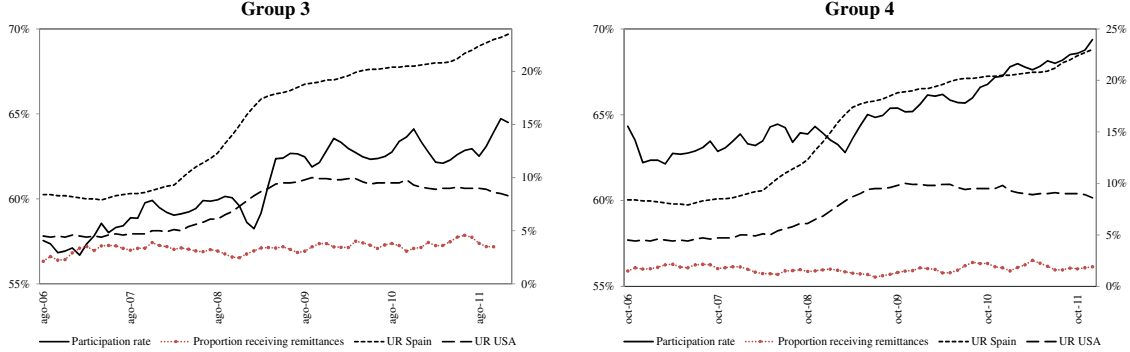

Fig. 3 Unemployment rates in Spain and US, labor participation rate, and proportion of households that received remittances. 2006-2011. The left vertical axis measures participation rate. The right vertical axis measures unemployment rate of Spain and US and the proportion of households receiving remittances in the last 12 months. Source: DANE: ECH-GEIH. The unemployment rates of Spain and the US were obtained from http://data.bls.gov/pdq/SurveyOutputServlet; authors' calculations

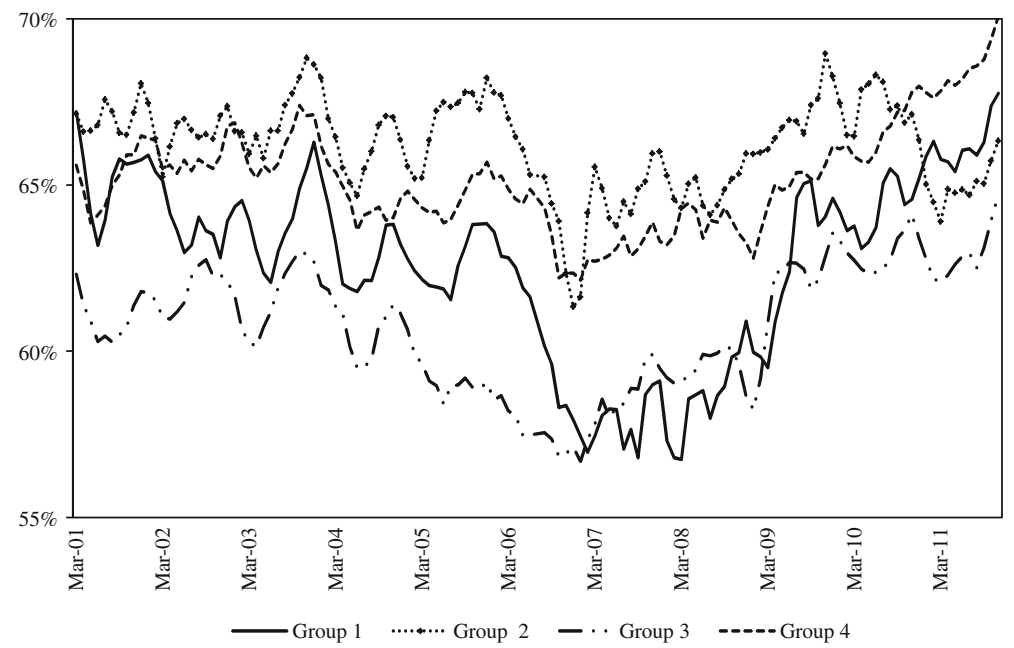

Fig. 4 Participation rate in 13 municipalities grouped by migration rates 2001-2011. Source: DANE: ECH-GEIH; authors' calculations

mation about the family members living in foreign countries. The only information available related to family members living abroad is through the receipt information of remittances. However, the fact that the household does not receive remittances does not imply that the household does not have a family member living abroad. This data lim- 
itation prevents us from conducting our analysis comparing labor force participation behavior of individuals with and without relatives living abroad.

The second outcome of interest is household size. This outcome allows us to analyze whether the worsening of economic conditions in main destinations of Colombian migrants is inducing those migrants to return back to Colombia. The third outcome of interest — at the individual level—is whether an individual participates in the labor force. We construct a dummy variable taking the value of 1 if the individual participates in the labor market and zero otherwise.

We restrict our analysis to individuals aged between 12 and 75, living in the largest Colombian urban areas. These are: Barranquilla, Bucaramanga, Bogotá, Cali, Cartagena, Cúcuta, Ibagué, Manizales, Medellín, Montería, Pasto, Pereira, Villavicencio. These 13 areas comprise 33 municipalities (see Table 1).

Other individual characteristics included as control variables in the regression analysis are age, years of education, marital status, household headship, the presence and number of children under age 7 living in the household, dummies for municipality of residence, and individual's region-of-residence characteristics, such as the unemployment rate of the age-group the individual belongs to. ${ }^{12}$

Some of our empirical specifications below include a whole set of month and year dummies (and their interactions) to capture the Colombian business cycle. Alternatively, as a proxy of the internal macroeconomic conditions, we use an index called the "Accumulated Diffusion Index" (see Alfonso et al. 2013). We additionally consider the gross regional domestic product growth (available from DANE at the department level, on an annual basis) to control for region-specific business cycle.

As Table 1 shows, Spain and US are the main destinations of Colombian immigrants. Then, as an indicator of economic conditions in these countries, we consider their unemployment rate. Given that remittances receipt refers to the last 12 months, we construct for any period $t$ (month-year) the average unemployment rate in the last 12 months (including the current month). ${ }^{13}$

\section{Empirical strategy}

Our first goal is to identify the causal effect of economic conditions of countries which are the main destinations of Colombian migrants on the probability of Colombian household's receiving remittances and the total amount in areas with high and moderate migration rates relative to cities with very low migration. The second goal is to identify the causal effect of these countries' economic conditions on individual labor force participation decisions. Finally, given that during an important fraction of the sample period the economic conditions of the main Colombian migrants host coun-

\footnotetext{
12 This variable is intended to capture particular conditions of the segment of labor market in which the individual is focused. It is computed as the relation between people looking for a job and the working population within each age range.

13 We did all our estimations constructing this average excluding current month. Results are not shown here but are available upon request.
} 
tries worsened, we also explore an additional channel through which foreign economic conditions may affect local labor markets: the return of Colombian emigrants. ${ }^{14}$

One of the difficulties posed by the verification of the hypothesis that remittances affect the reservation wage of recipients and, hence, affects labor force participation decisions, is that remittances are potentially an endogenous variable. That is, households receiving remittances may differ from those that do not receive them in some unobservable dimensions, which could also be correlated to labor force participation decisions (see Table 2).

In order to identify the effects of interest and overcome the endogeneity problems, we implement a DD approach which relies on the following two sources of variation. First, we exploit regional heterogeneity in the proportion of households at the municipality level who have family members living abroad (see Table 1). This regional variation allows us to construct treatment and control groups. Treated individuals are those residing in Colombian municipalities with high and moderately-high migration rates, which are more likely to be exposed and affected by the changing economic conditions of immigrants' host countries. In our baseline specification, treated individuals are those living in municipalities with more than $5 \%$ of the households with at least one family member living in either Spain or US. We divide these cities in two groups: Treatment $\mathrm{H}$ (municipalities from Group 1, that is with high emigration rates), and Treatment $\mathrm{M}$ (municipalities from Group 2, that is with moderate emigration rates). In the control group there are municipalities with very low emigration rates (Group 4), which are less likely to be affected by the changing economic conditions in foreign countries. In our baseline specification, individuals in the control group are those residing in municipalities with less than $2 \%$ of the households with at least one family member living in Spain or the United States. ${ }^{15}$

The second source of variation we exploit is the notable change of the economic conditions that occurred in Colombian immigrants' host countries in the period 20062011. The worsening economic conditions in the US and mainly in Spain, which we argue were not completely expected, allow us to analyze the changes within a period of time in outcomes of interest of treated individuals relative to control individuals. We use either the Spanish unemployment rate or US unemployment rate to proxy the economic conditions of these countries. In the time period analyzed, these two measures are highly correlated. Hence, we do not attempt to disentangle which part of the effects are explained either by the changing economic conditions of the US or Spain.

Let variable $Y_{i t}$ indicate whether household $i$ received remittances in the twelve months prior to time $t$ (or the total amount of remittances received). In this case the $Y_{i t}$ takes the value of 1 and 0 otherwise. Our model specification is:

$$
Y_{i t}=\alpha+\beta_{1} \text { Treat }_{i}^{H} \times \text { unemp }_{t}+\beta_{2} \text { Treat }_{i}^{M} \times \text { unemp }_{t}+\delta^{\text {Mun }}+\delta^{t}+X_{i t}^{\prime} \gamma+u_{i t},
$$

\footnotetext{
14 Recently, Arango et al. (2013) showed that remittances are a determinant of labor force participation in the country as a whole, and larger in Pereira, Dosquebradas and La Virginia.

15 Municipalities with an intermediate proportion of households with at least one family member living in Spain or US (between 2 and $5 \%$ ) are left out of the baseline analysis, but used lately for a placebo analysis.
} 
where $\operatorname{Treat}_{i}^{j}$, for $j=\{\mathrm{H}, \mathrm{M}\}$, indicates whether household $i$ lives in a municipality with high or moderately-high migration rates; unemp $_{t}$ is the average unemployment rate in either Spain or US in the 12 months prior to period $t ;{ }^{16} \delta^{M u n}$ are municipality of residence fixed effects; $\delta^{t}$ are period (year-month) fixed effects; and $X_{i t}^{\prime}$ is a vector of household head's individual characteristics, other household's members characteristics and aggregated regional characteristics.

Time fixed effects $\left(\delta^{t}\right)$ in Eq. (1) allow us to control for common time trends in control and treatment groups, while municipality fixed effects $\left(\delta^{M u n}\right)$ capture timeinvariant differences across Colombian municipalities. The parameters of interest in the specification (1) are $\beta_{1}$ and $\beta_{2}$, which capture any difference in remittances received between the treatment and control municipalities when the economic conditions of Spain and US worsened. ${ }^{17}$

In order to explore whether worsening economic conditions in the foreign countries are inducing immigrants to return to their origin municipalities in Colombia, we estimate Eq. (1) using the household size as the outcome variable. This variable is used instead of others that indicate whether individuals have migrated recently, because this information is not available from the survey.

If remittances discourage labor force participation of non-migrants through its income effects, we should observe that individuals in the treatment regions are more likely to participate-vis-à-vis individuals in control regions-whenever Colombian immigrant hosting countries are undergoing bad times, when immigrants are less likely to send remittances to their relatives in Colombia. In this case, we estimate specification (1), but $Y_{i t}$ turns to be the labor participation decision of individual $i$ in time $t$. It takes the value of 1 if the individual participates in the labor market and zero otherwise.

A potential concern with specification (1) is that we are assuming that there is no other shock in treatment areas different from changes in economic conditions of Colombian immigrant host countries, which simultaneously affects the labor force participation decisions. ${ }^{18}$ This assumption would be violated if, for instance, there are region-specific trends which are not captured through the time-invariant municipality fixed effects. To mitigate this potential problem, we specifically include as a control variable the gross regional domestic product growth.

\footnotetext{
16 Due to collinearity between these two unemployment rates, they are not used simultaneously in any specification.

17 The $\beta$ 's should be interpreted as "intention to treat estimates", given that not all individuals in the treated regions actually have a family member living abroad which could send remittances. Of course, having a family member living abroad is neither a sufficient nor a necessary condition to receive remittances. However, to have at least one increases the probability of receiving them.

18 One could argue that the effects of the slowdown in Spain and USA might affect the labor participation in municipalities of Groups 1 and 2 through any other channel but remittances. For example, what if exports from these groups to Spain and USA become affected by the business cycle in these countries? However, we do not think this is the case since Spain does not appear as one of the main destination of exports from those provinces according to information from the DANE and Tax Office (DIAN). By contrast, the average proportion of exports to USA from Risaralda between 2000 and 2013 was about $42 \%$ while from Valle del Cauca it was about $16 \%$. The former corresponds to municipalities of Group 1 while the latter corresponds to the province of Cali and Yumbo. Thus, the channel from the phase of economic activity had to be different from exports, at least to Spain.
} 


\section{Results}

\subsection{Reception of remittances}

Table 3 reports the OLS estimates of specification (1) where the outcome variable is either a dummy variable that equals one if the household received remittances in the last 12 months and zero otherwise (panel A), or the log of the total amount of remittances received during that period (panel B). All the coefficients reported in the table correspond to the estimates of the parameters $\beta$ 's which capture any difference between the treatment and control groups in the remittances received whenever economic conditions in Colombian migrants' host countries worsen. Each column reports the same estimate including a different set of control variables. Results in the first row of panel A.1 of Table 3 indicate that a 1 percentage point increase in the Spanish unemployment rate reduces the probability of receiving remittances in municipalities with high emigration rate (Treat $\mathrm{H}$ ) by $0.13-0.15 \%$ points, relative to control municipalities and by $0.17-0.18 \%$ points in municipalities with moderate emigration rates (Treat M). The patterns observed in panel A.2, where we proxy economic conditions in US with the unemployment rate of that country, are similar to those in panel A.1, although the magnitude of coefficients is higher. ${ }^{19}$

Results in the first row of panel B.1 indicate that a 1 percentage point increase in the Spanish unemployment rate also reduces the amount of remittances received by $0.15-0.18 \%$ in high emigration municipalities and by $0.23-0.24 \%$ in moderately high emigration rate municipalities. The estimated effects more than double when considering the US unemployment rate, but the pattern remains the same.

Results in Tables 4 and 5 show the heterogeneous effects on the probability of receiving remittances and their amount by gender of the head of the household and by education level. Taking into account these heterogeneous effects may be important given that, according to census data, households with emigrated relatives tend to have heads of household with lower educational attainment. Additionally, according to the survey data, households that receive remittances are more likely to have a female as the head of the household. As expected, we find that female-headed households and those with less educated heads (11 years of education or less) are slightly more likely to be affected than the average household.

\subsection{Household size}

Table 6 shows the OLS estimates of Eq. (1) using the family size (number of household members) as the outcome variable. If emigrated individuals are returning to Colombia, the family composition and, in particular, the family size of households residing in treatment municipalities may be changing relative to control municipalities. However,

\footnotetext{
19 We performed these regressions at the individual level using as outcome a variable that equals one if the individual reported receiving remittances in the last 12 months. We find that unemployment rates of Spain and US reduce the probability of receiving remittances in the last 12 months only for individuals with less than 11 years of education and those who are head of household. By contrast, we do not find effects for other type of individuals (women or men separately, nor for individuals who are not head of the household).
} 


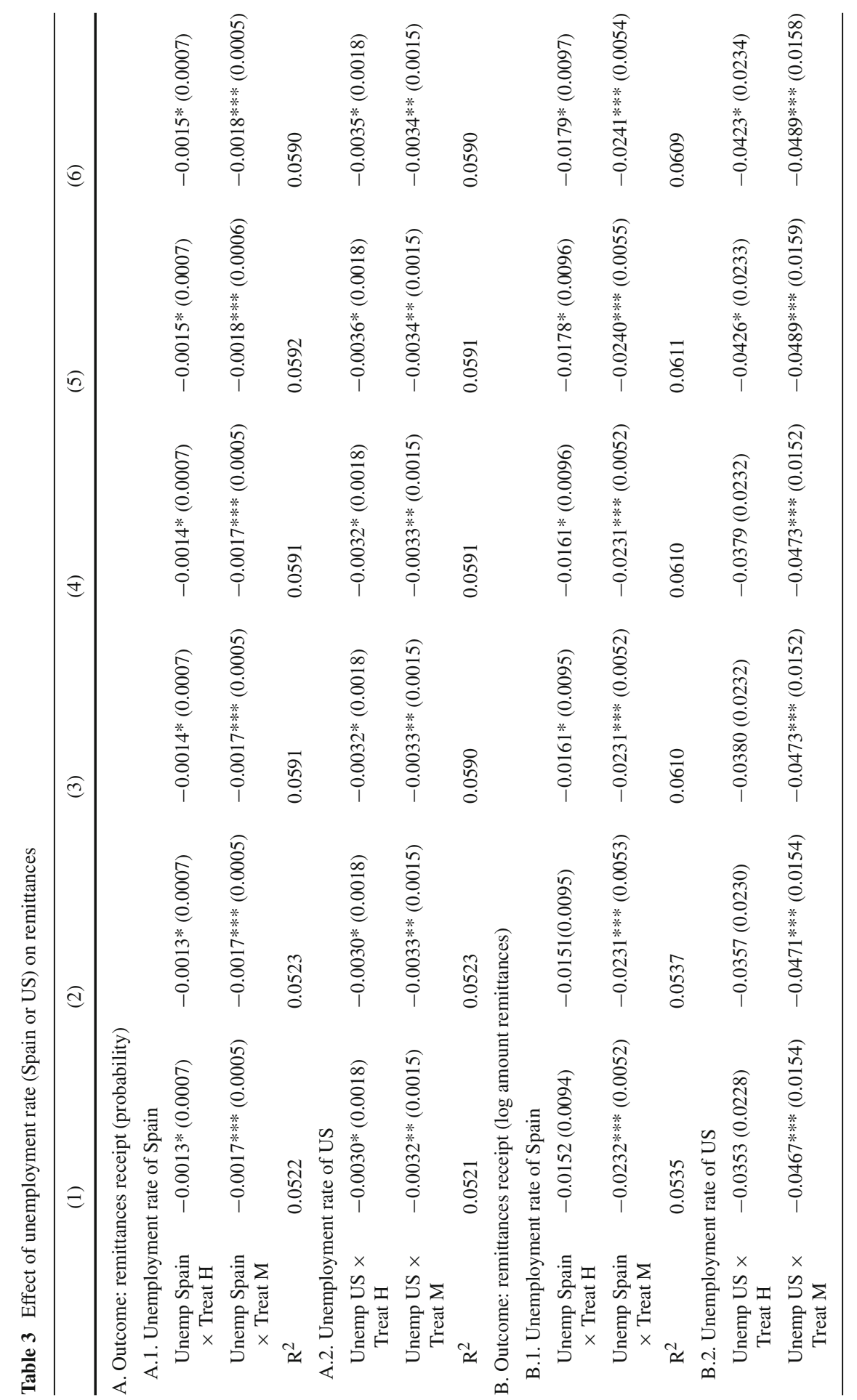




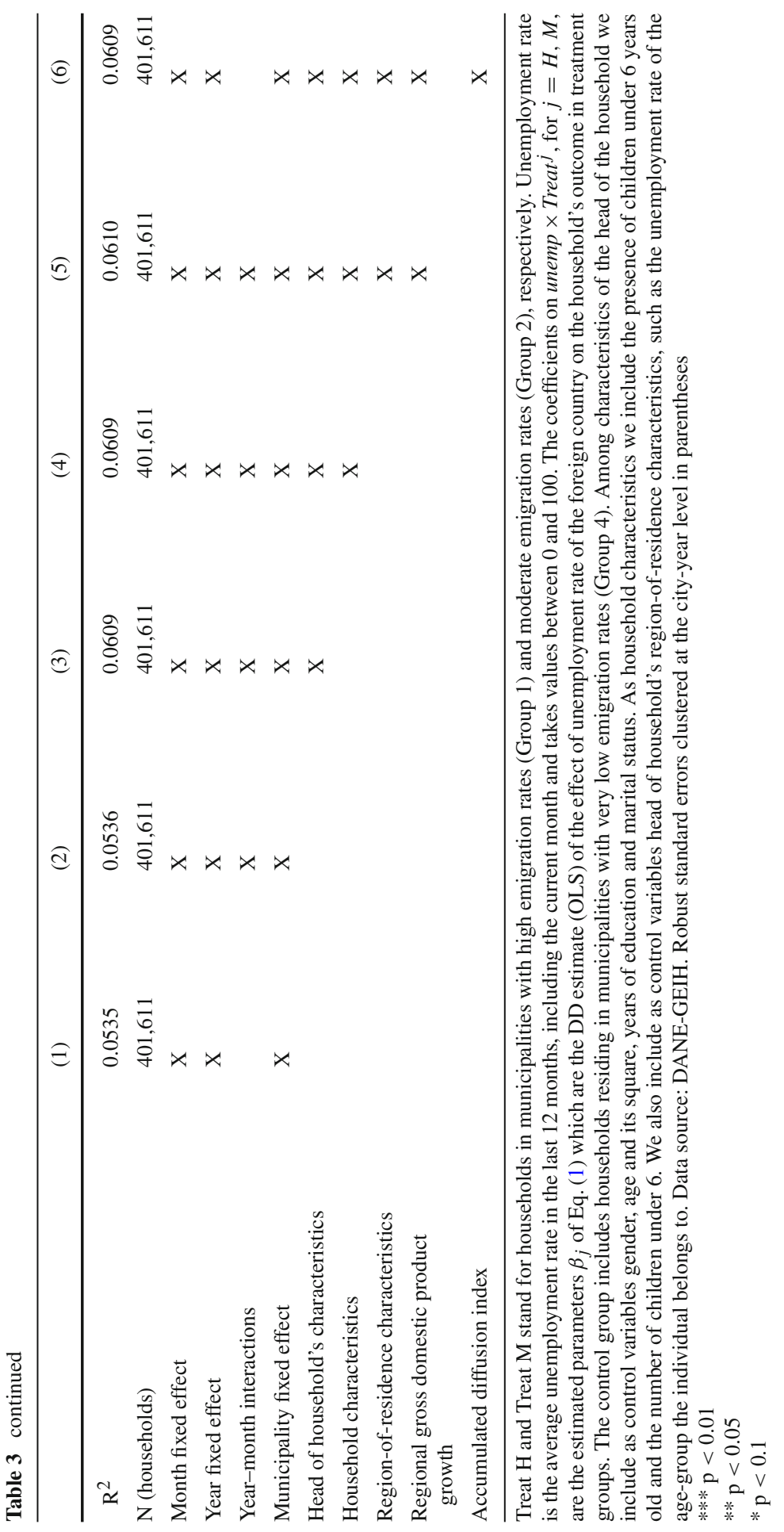




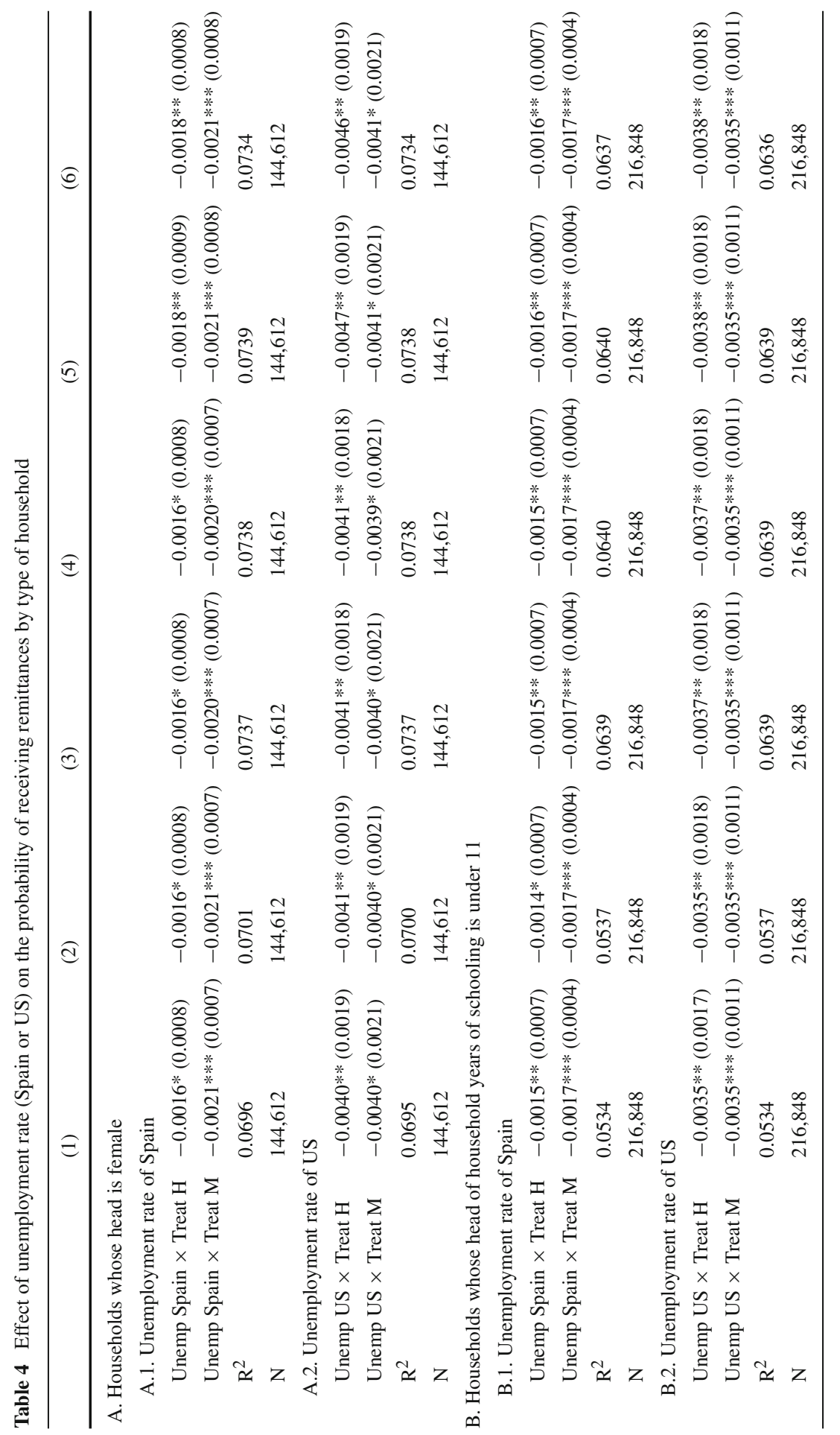




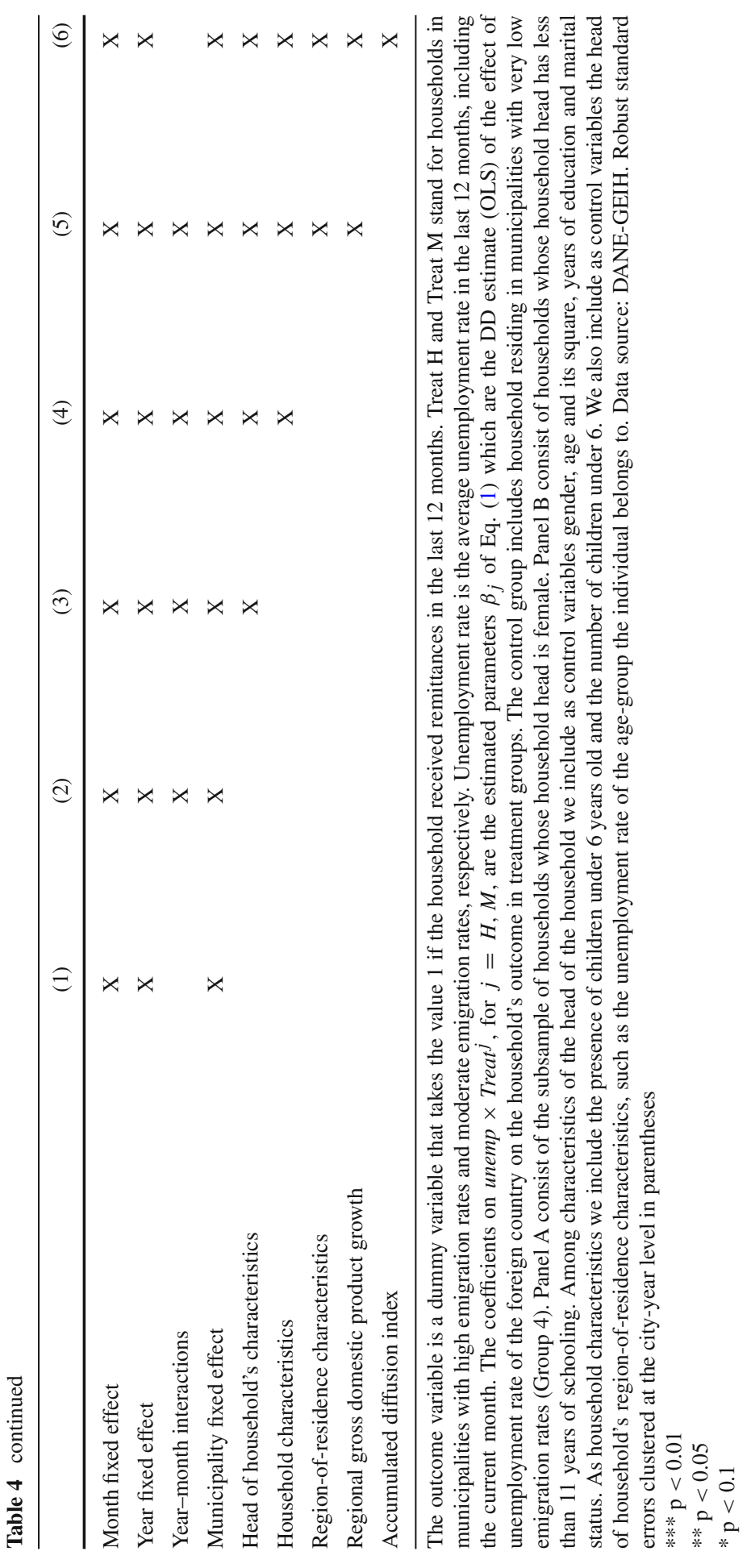




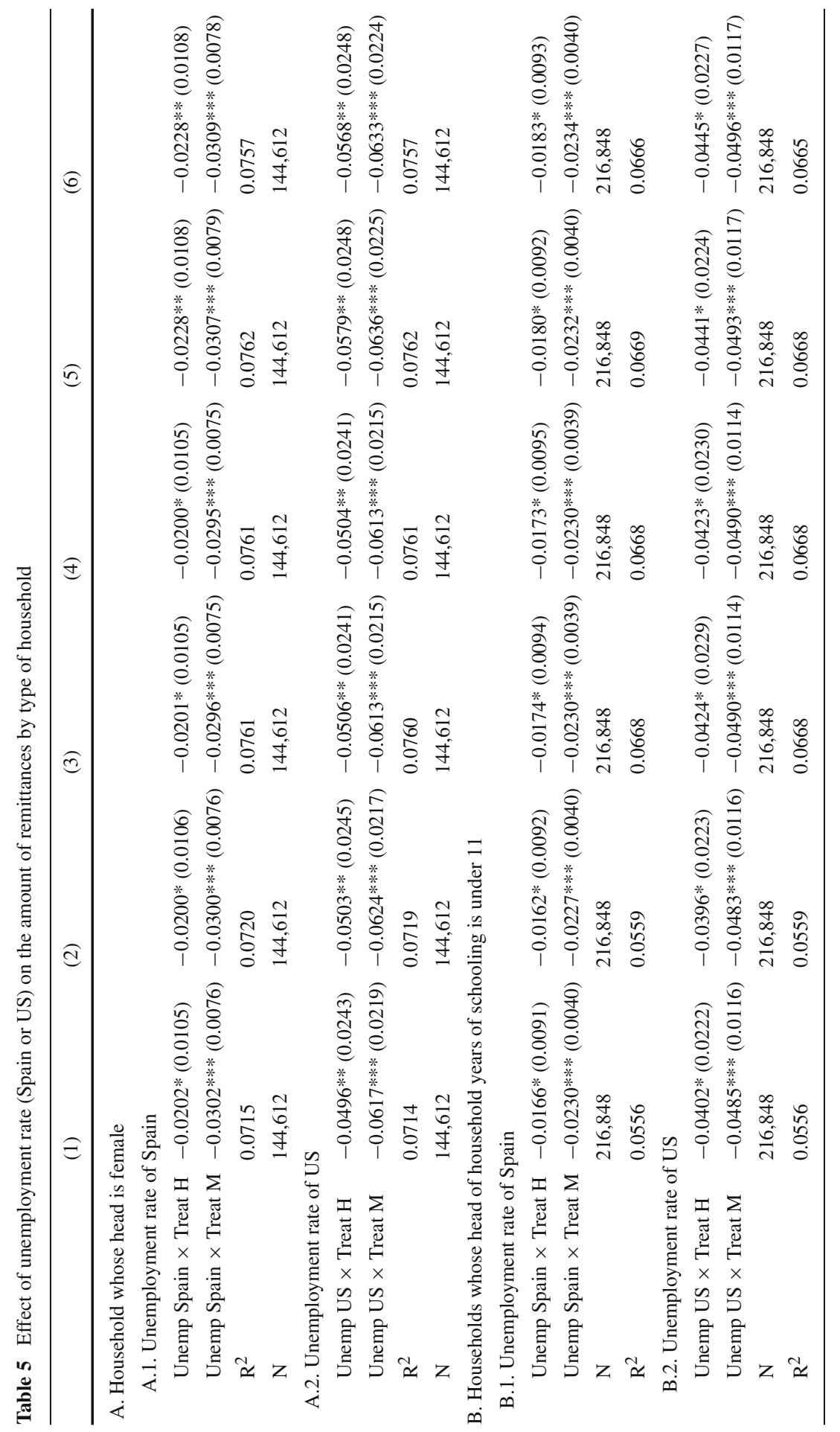




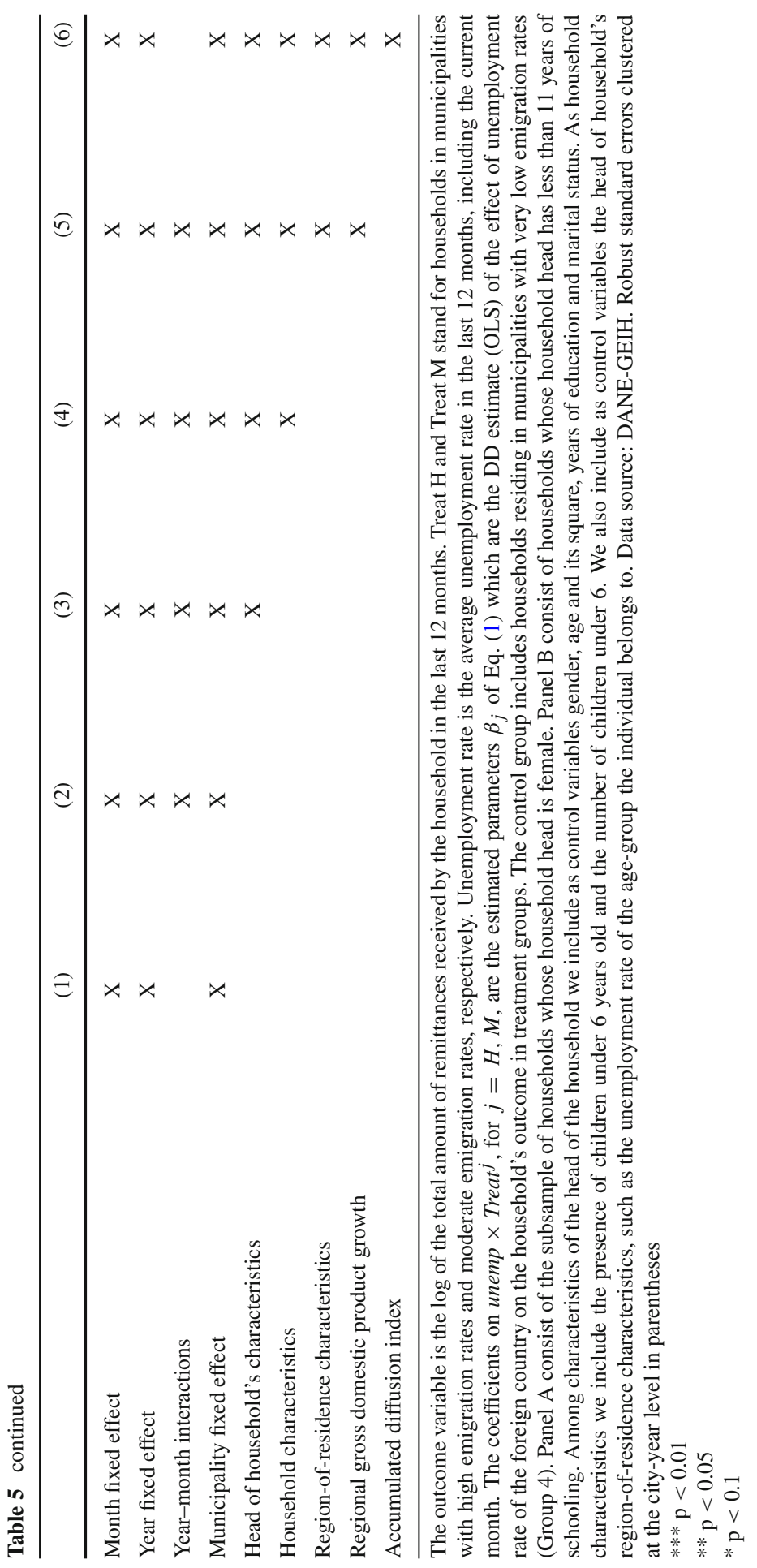




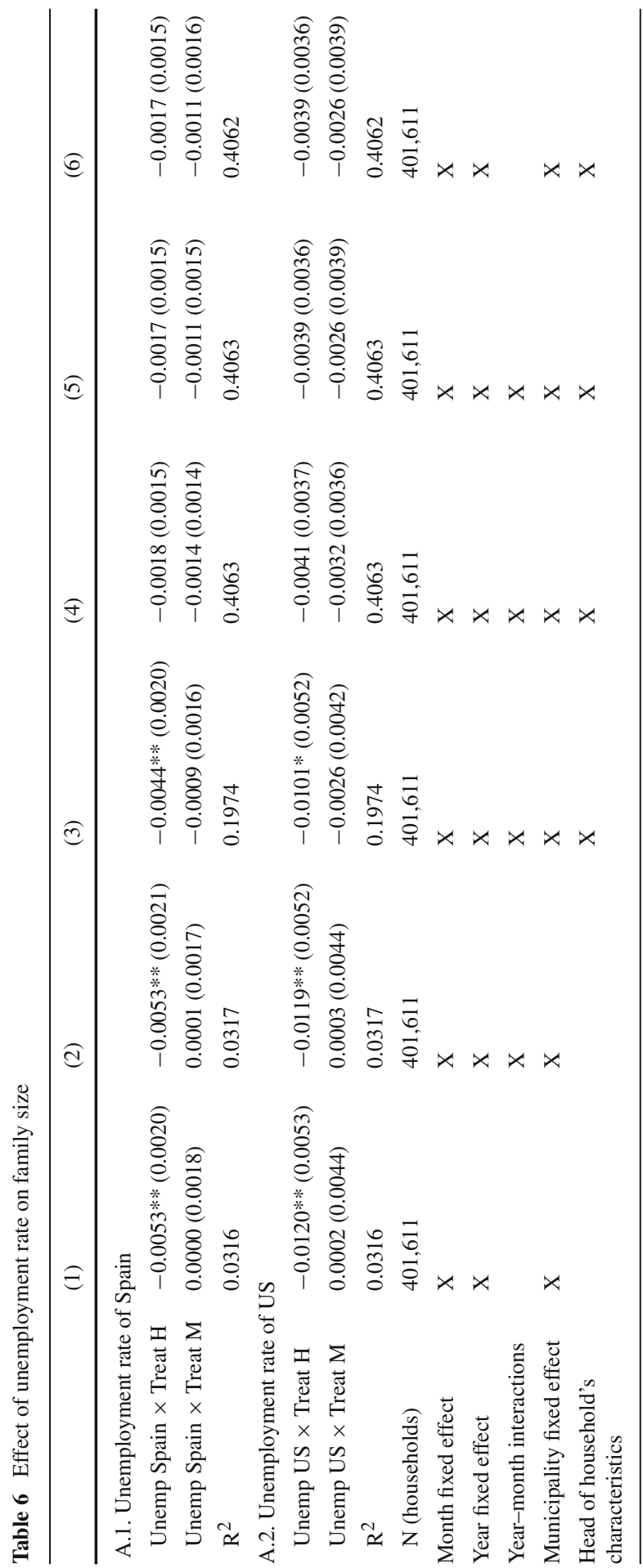







results in the table indicate that there is no effect on family size. This result supports the idea that the effects of migration on labor force participation decisions of non-migrants may not be explained by returning migrants.

\subsection{Individual labor force participation}

Table 7 shows the OLS estimates of Eq. (1) where the outcome variable is individual labor participation decision. Panel A presents the results for all individuals in the sample. The estimates suggest that the probability that an individual has a job or looks for one increases with the unemployment rate of Spain only in high emigration rates. Specifically, a $1 \%$ point increase in unemployment rate increases the probability of participating in the labor market by $0.31-0.36 \%$ points, and the results is statistically significant for all specifications. This result holds when we use the US unemployment rate, although the magnitude doubles. Unemployment rates of foreign countries do not have any effect on the labor force participation decisions of individuals residing in municipalities with moderate emigration rates, despite the presence of remittances effects.

To gain intuition about this result, it is important to mention at this point that aggregate remittances are more important in the province of Risaralda than in Valle del Cauca. Recall that the former corresponds to municipalities of Group 1, while the latter corresponds to the province of Cali and Yumbo. The ratio of remittances to the Gross Regional Product of Risaralda was 14, 12 and $10 \%$ in 2009, 2010 and 2011, respectively. For the case of Valle del Cauca these ratios were 5, 4 and $4 \%$, respectively. This differential dependence of remittances may explain why they affect labor participation in municipalities from Group 1 but not in municipalities from Group 2.

When the sample is divided by gender, we find the same patterns as with the full sample (see Table 7, panels B and C). However, the effects are substantially higher for females than for males. Under some specifications, we find a statistically significant negative effect of the unemployment rate of Spain on labor force participation decisions of males in municipalities with moderately high migration rates. However, this result is not robust when the regression is run with the unemployment rate of the US.

A possible explanation for the higher sensitivity of female's labor force participation to changes in foreign countries economic conditions is that remittances have a stronger effect on the labor force participation decisions of secondary workers of the household. Panel D of Table 7 explores this directly by considering the subsample of individuals who are not head of the household. For all specifications, the estimated coefficients for high emigration rate municipalities are statistically significant and larger than the average effects of panel A. Finally, we analyze whether changes in external economic conditions may affect the labor participation of children. Panel E of Table 7 shows the effects of unemployment in Spain and the US on the probability of children between 12 and 15 years old participating in the labor market. Interestingly, we find positive effects on children's labor force participation decisions. The magnitude is approximately half of the average effect on the whole population, but it is still statistically significant in specifications with the broader set of controls. 


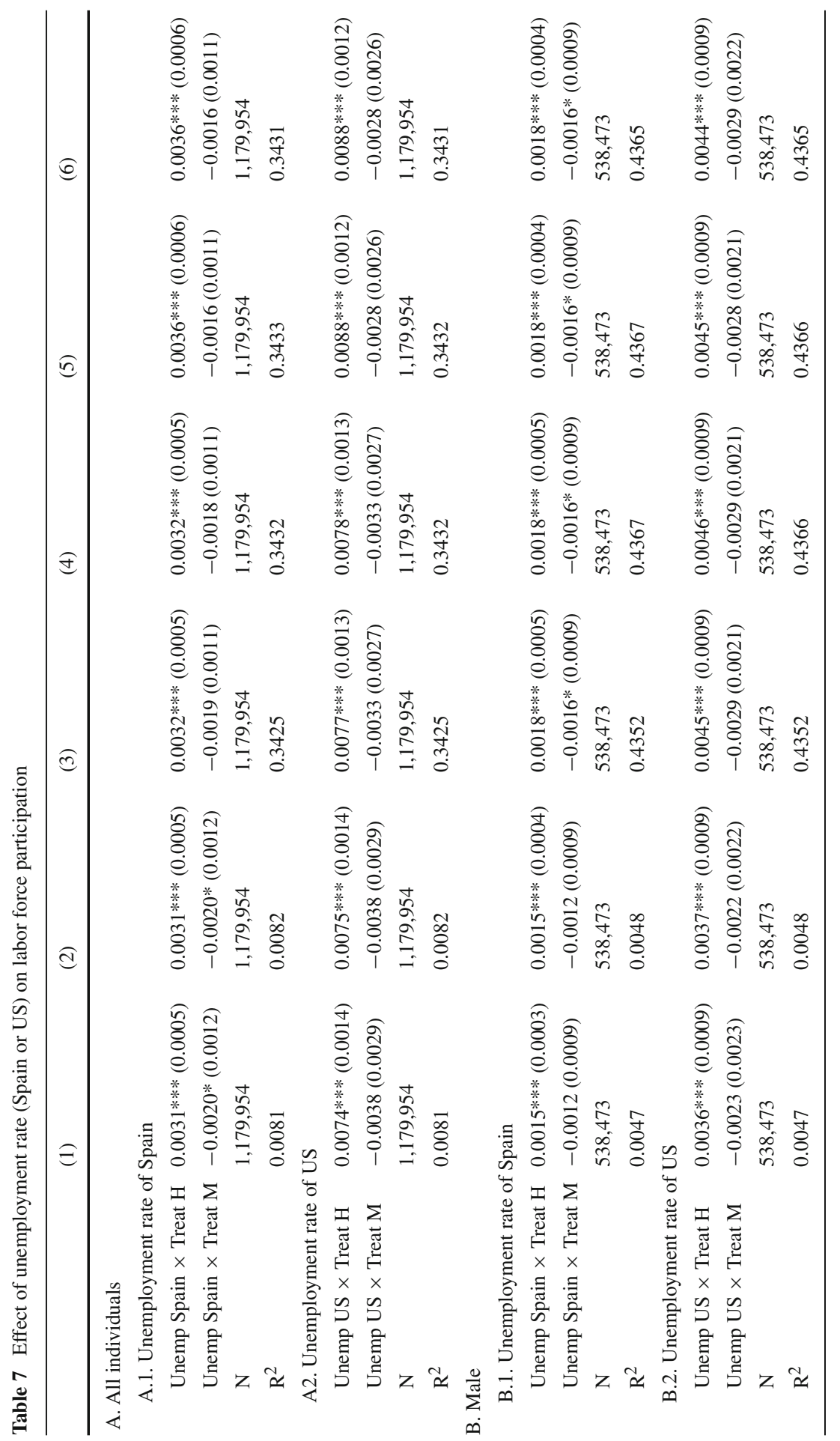




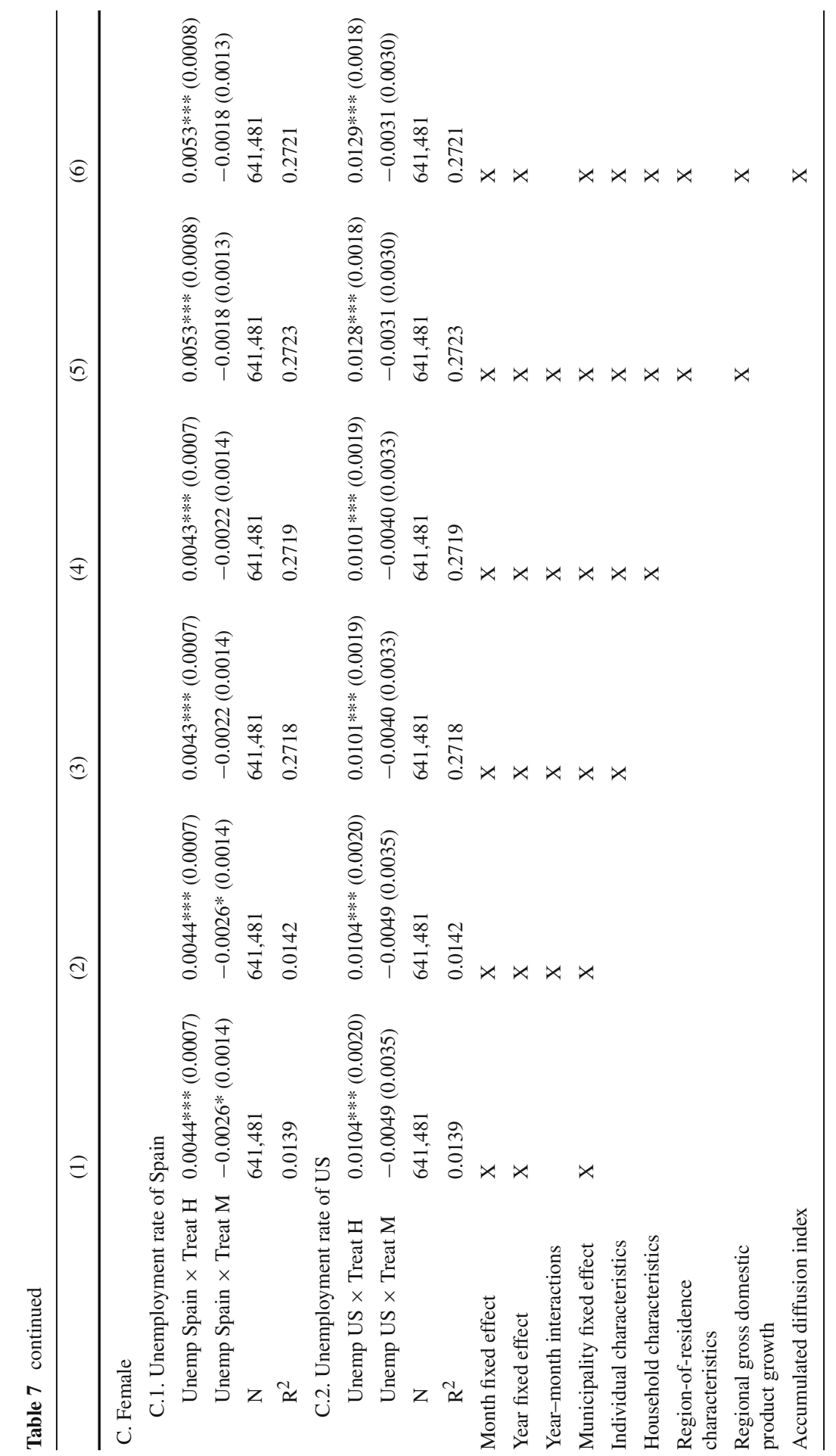




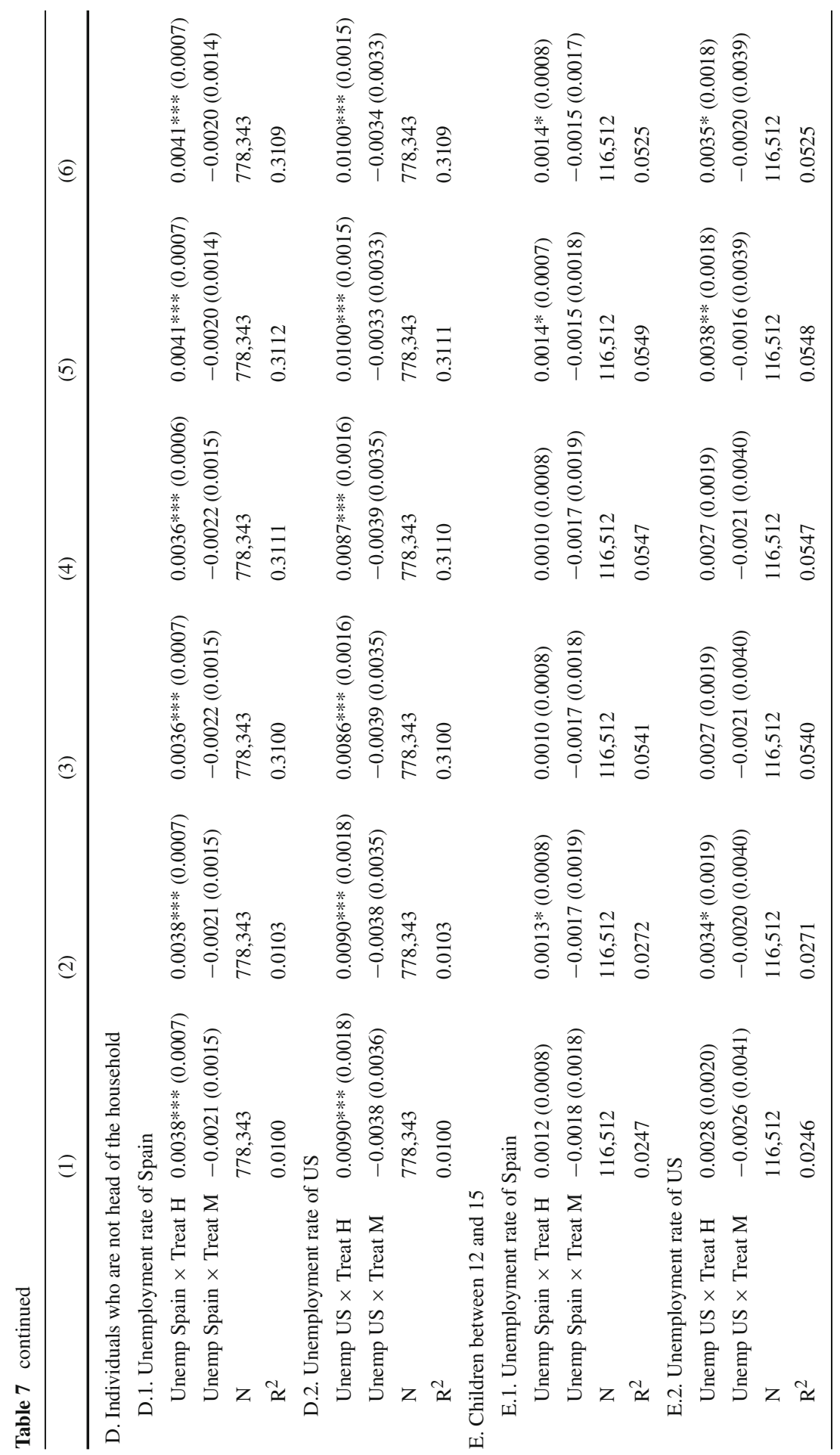




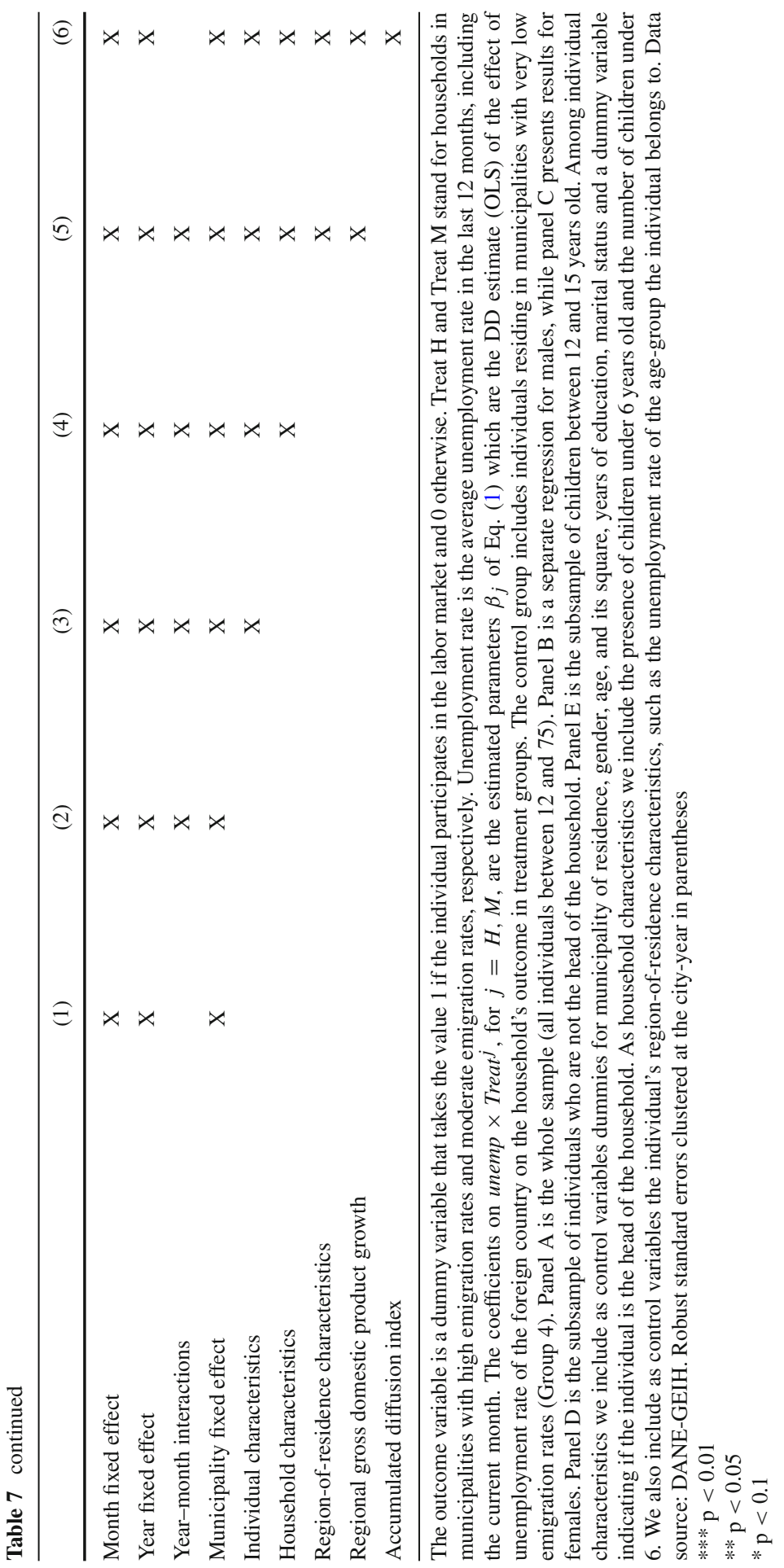




\section{Robustness analysis}

This section presents a series of robustness checks we performed to validate our previous results. $^{20}$

\subsection{Placebo regressions}

We re-estimate previous regressions keeping the same municipalities as control group but replacing the treatment group with a placebo composed of individuals and households living in municipalities with a low proportion of households (between 2 and $5 \%$ ) with at least one family member living in Spain or US (Group 3). Given the low proportion of households with emigrated relatives in these municipalities, we do not expect correlation neither between unemployment rate of foreign countries and remittances reception nor between the unemployment rate of foreign countries and labor force participation. Results in Table 8 are consistent with this prediction. We do not find any effects on remittances nor in labor force participation.

\subsection{Definition of control group}

We check whether our results are robust as to the definition of the control group. We re-define the control group as: (i) those municipalities with a proportion of households with at least one family member living in Spain or US below $3 \%$; (ii) those municipalities with a proportion of household with at least one family member living in Spain or US below $5 \%$. In both cases, the results remain quantitatively the same for all outcomes.

\subsection{Shortening time period of analysis}

Our empirical strategy relies on the assumption that the increase in unemployment rates in Spain or US was unexpected for Colombian households. This assumption could be more plausible during the first years of the Spanish and US crises. Hence, to analyze the sensitivity of our results to the time window of analysis, we drop the year 2011 from the regressions. Again, all the results remain quantitatively similar for all outcomes.

\subsection{Subsample of individuals that do not receive remittances}

We restrict the analysis to those individuals in households that did not receive remittances in the 12 months prior to the interview, hence, those who are less likely to be exposed and affected by the changes of external economic conditions. This is an imperfect proxy of not having family members living abroad because not receiving remittances does not imply that they do not have relatives abroad. Despite its limitations, we expect the effects of unemployment rates of Spain or US on labor force participation decisions to be lower for this subgroup as compared to those we report in

20 Some of the results of this section are not reported here, but are available upon request. 


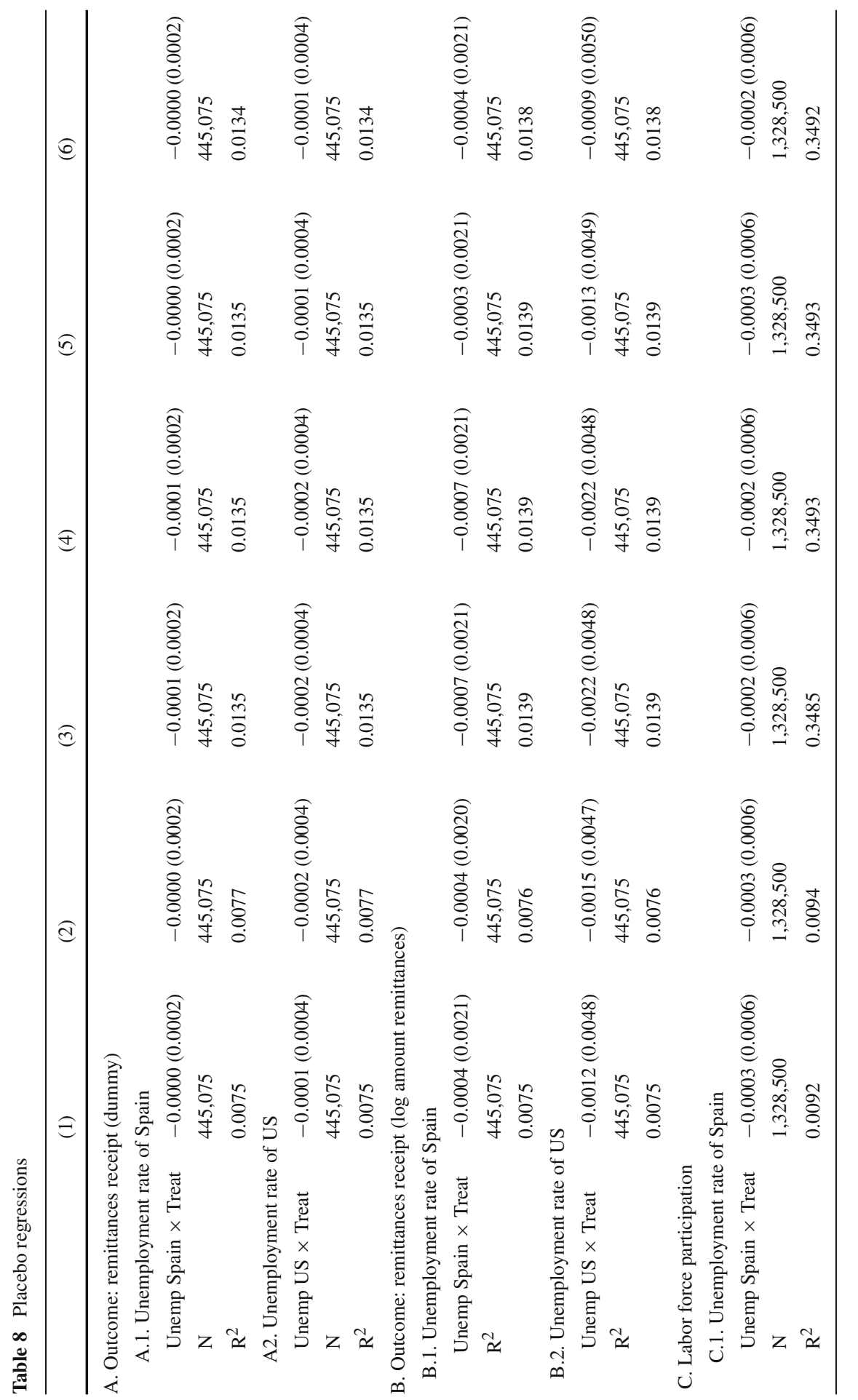




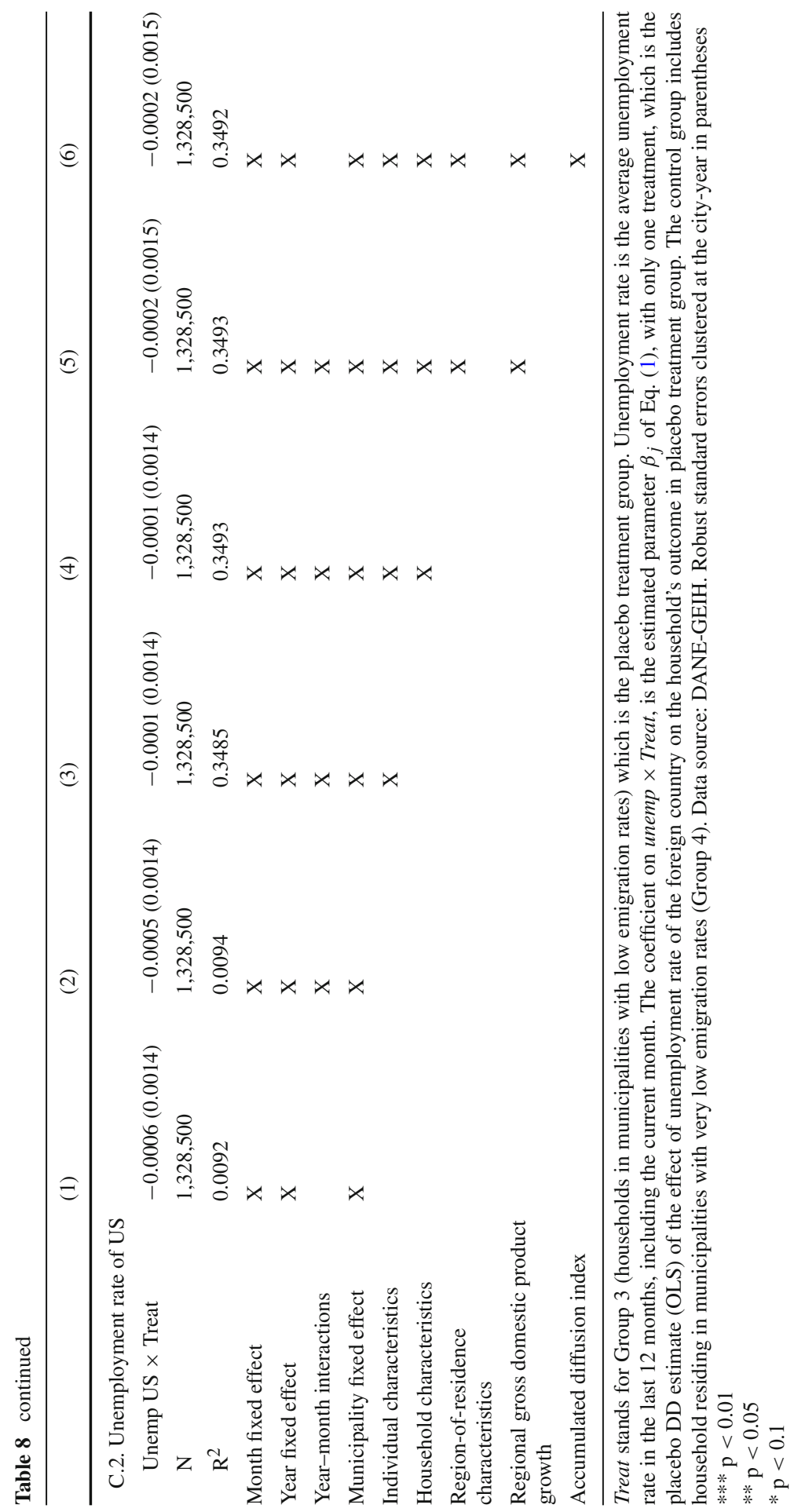




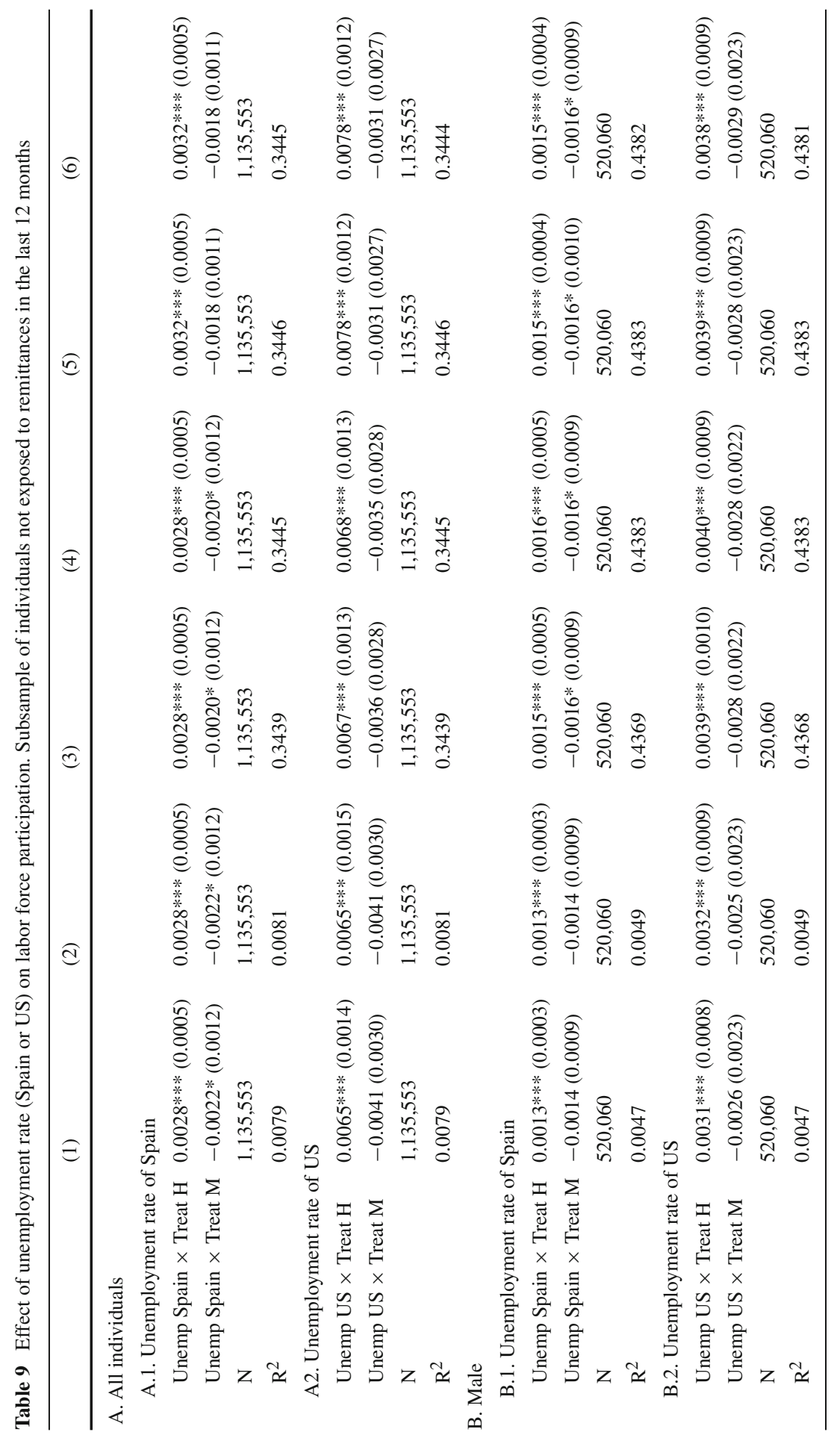




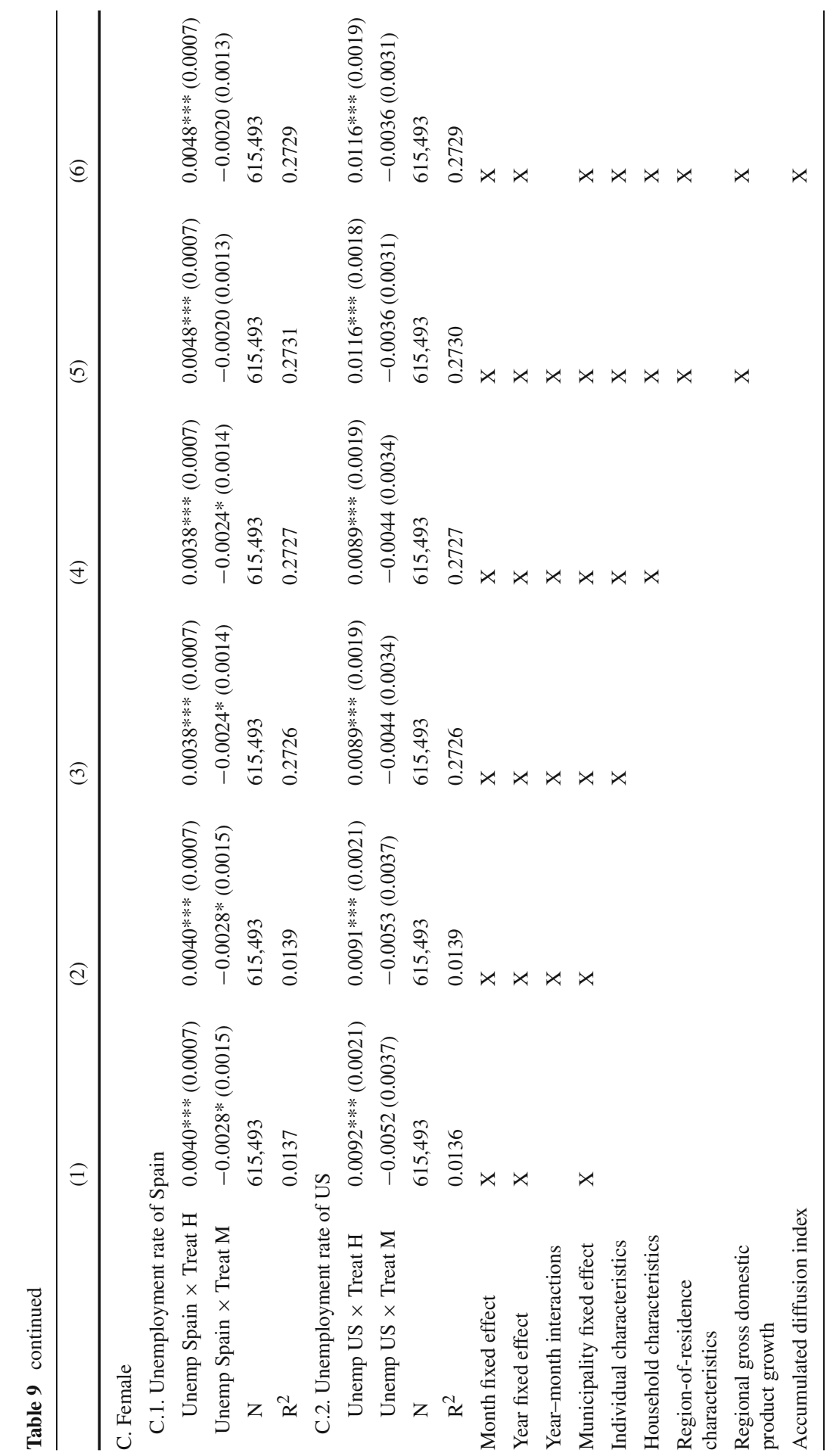




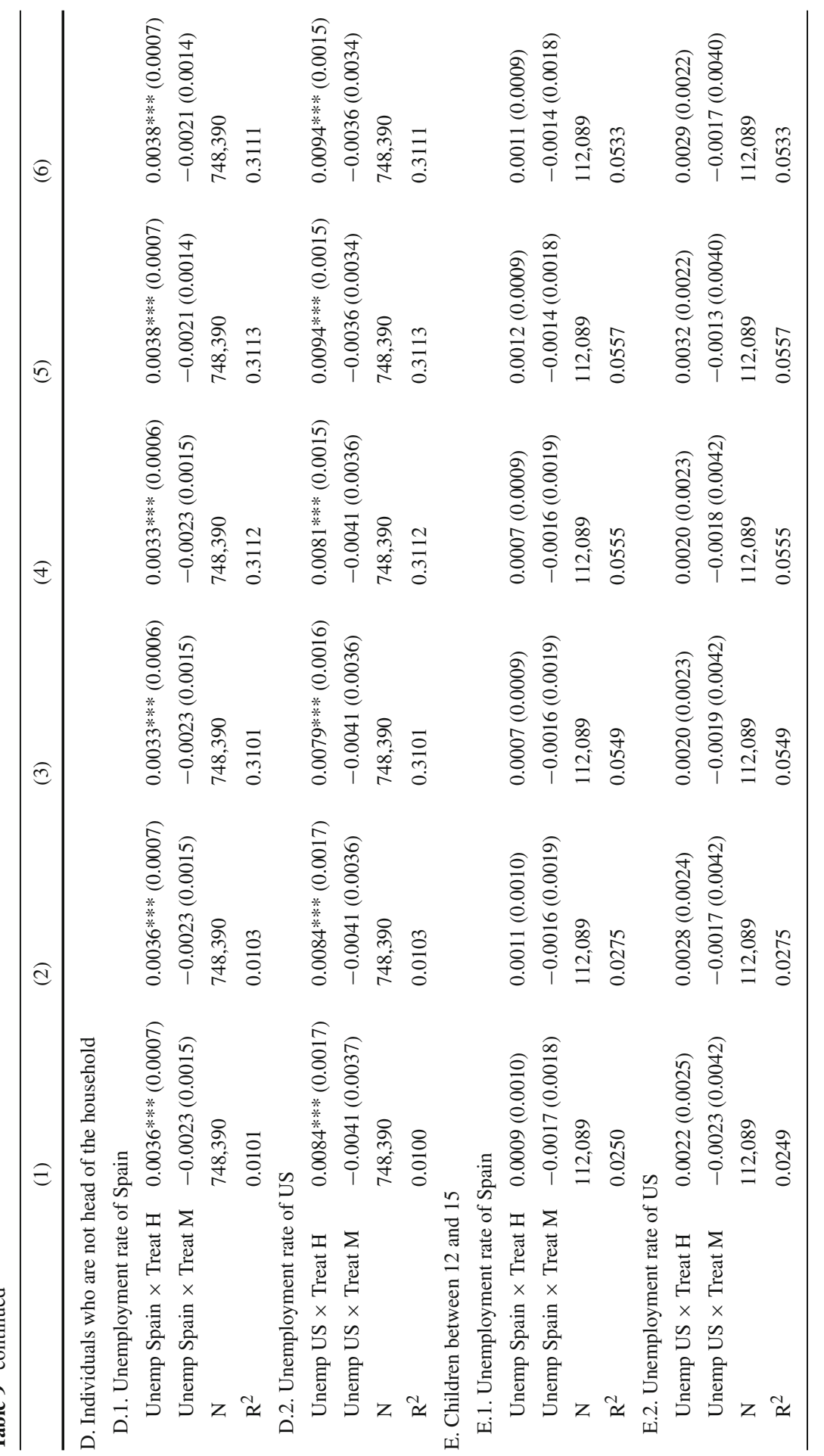




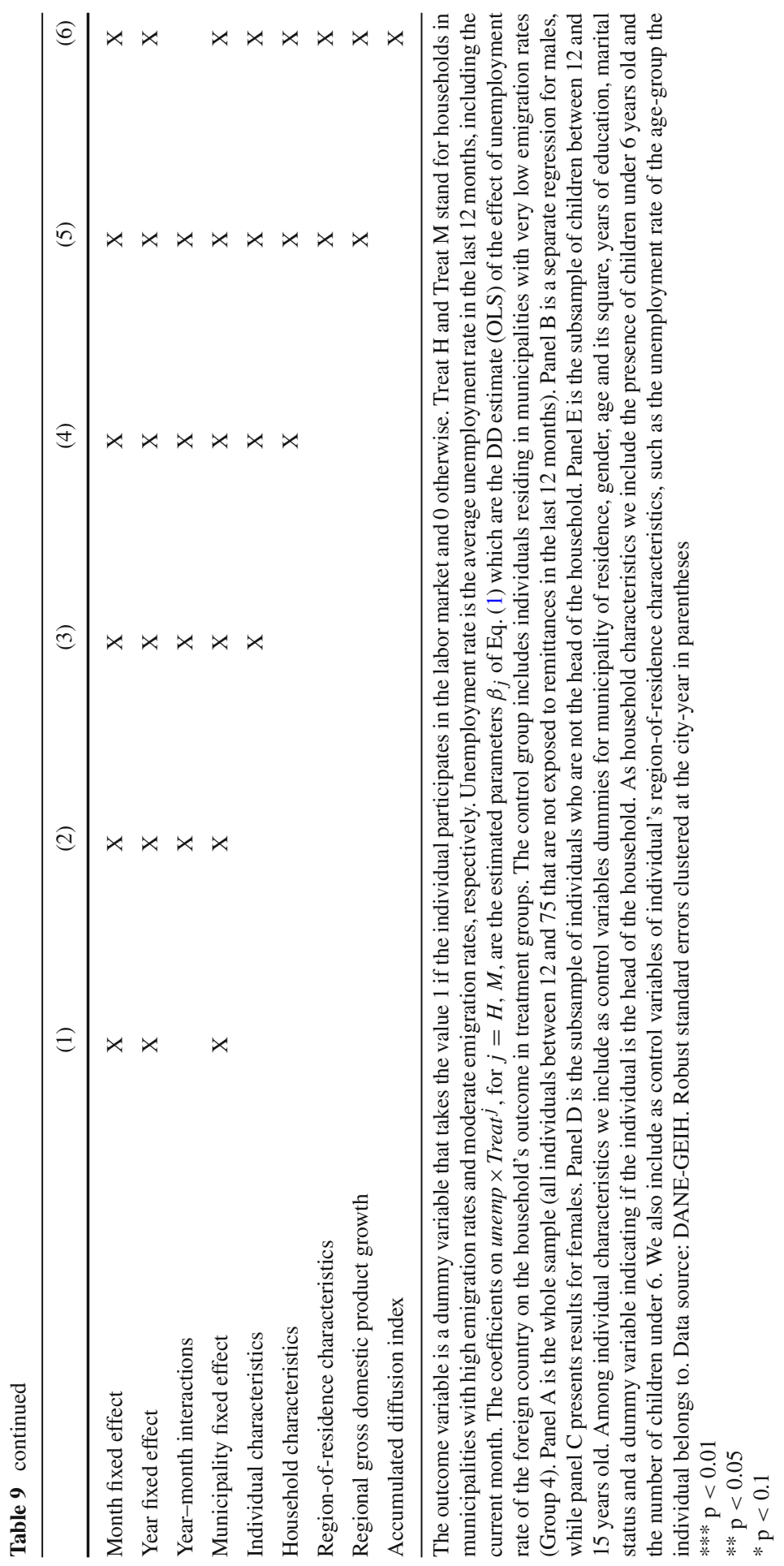


Table 7, where we include all individuals irrespective of whether they report receiving remittances or not.

Table 9 shows that, indeed, for all the subsamples analyzed the effects on unemployment rate are lower than those in Table 7. Still, the coefficients are statistically significant for the group of high emigration rates.

\section{Conclusions}

We use information from household surveys between 2006 and 2011 to test the hypothesis that income effects transmitted by remittances sent from Spain and US, affect the Colombian labor market. Specifically, there is a differential effect in areas with the highest emigration rates.

Given the potential endogeneity of the reception of remittances, we use a two-step approach within a differences-in-differences framework to identify the effects of interest. In the first step, we test the hypothesis that business cycles in the host countries of Colombian emigrants affect the probability of receiving remittances and their amount in the municipalities with high and moderate emigration rates as compared to municipalities with very low migration rates. In the second step, we test the hypothesis that economic conditions in Spain and US affect the labor participation of non-migrants. The hypothesis holds only for municipalities with high emigration rates. In the interim, we also checked whether the size of families has changed due to the reversal of fortune of the host countries, finding no effect.

This indirect way of testing the link between Spain, US and Colombian labor markets supports the statements of economic and political authorities, especially in cities of high emigration rates (Pereira, Dosquebradas and La Virginia) about the changes in the flow of remittances as the explanation for the dynamics of local labor markets. Our study provides evidence that some cities in Colombia echoed the crises in Spain and US through the labor market, being the income effect of the remittances the transmission mechanism.

Open Access This article is distributed under the terms of the Creative Commons Attribution 4.0 International License (http://creativecommons.org/licenses/by/4.0/), which permits unrestricted use, distribution, and reproduction in any medium, provided you give appropriate credit to the original author(s) and the source, provide a link to the Creative Commons license, and indicate if changes were made.

\section{References}

Alfonso VA, Arango LE, Arias F, Pulido JD (2013) Ciclos económicos en Colombia. In: Lecturas de Economía, vol 78, enero-junio, pp 115-149

AMCO (2010) Identificación Puntos Críticos del Desempleo. Alcaldía de Pereira (consultor: J. O. Torres) Amuedo-Dorantes C, Pozo S (2010) Accounting for remittance and migration effects on children's schooling. World Dev 38(12):1747-1759

Amuedo-Dorantes C, Pozo S (2006) Remittances and insurance: evidence from Mexican immigrants. J Popul Econ 19(2):227-254

Arango L, Montenegro P, Obando N (2013) El desempleo en Pereira: ¿solo cuestión de remesas? In: Hammann LAF (eds) El mercado de trabajo en Colombia: hechos, tendencias e instituciones, Banco de la República 
Bargain O, Boutin D (2014) Remittances and child labour in Africa: evidence from Burkina Faso. In: IZA discussion paper no. 8007, Forschungsinstitut zur Zukunft der Arbeit

Borjas G (2000) Labor economics, 2nd edn. MacGraw Hill, New York

Bussolo M, Medvedev D (2007) Do remittances have a flip side? A general equilibrium analysis of remittances, labor supply responses, and policy options for Jamaica. In: World Bank policy research working paper 4143, World Bank, Bretton Woods

Cadena X, Cárdenas M (2004) Las remesas en Colombia: costos de transacción y lavado de dinero. Fedesarrollo, Documentos de Trabajo. No. 26

Cárdenas M, Medina C, Trejos A (2010) Measuring economic and social impacts of migration in Colombia: new evidence. Borradores de Economia, No. 601, Banco de la Republica

Castillo CM (2000) Determinantes de la probabilidad de estar desempleado en el Área Metropolitana de Cali: evidencias micro y macroeconómicas en el período 1988-1998, Universidad del Valle. Documentos de investigación, Universidad del Valle

Cox-Edwards A, Rodriguez-Oreggia E (2009) Remittances and labor force participation in Mexico: an analysis using propensity score matching. World Dev 37(5):1004-1014

Fajardo G, Gutiérrez E, Larreguy HA (2014) Taking one for the team: shocks at destination and household's supply of migrants. http://sites.bu.edu/neudc/files/2014/10/paper_386.pdf

Fajnzylber P, López JH (2008) El impacto de las remesas en el desarrollo de América Latina. In: Fajnzylber P, López JH (eds) Remittances and development, lessons from America Latina, World Bank, Bretton Woods

Funkhouser E (1992) Migration from Nicaragua: some recent evidence. World Dev 20(8):1209-1218

Garay L, Rodríguez A (2005) Características socioeconómicas de la población. en Memorias del seminario Migración internacional, el impacto y las tendencias de las remesas en Colombia, Ministerio de Relaciones Exteriores

Hanson G (2007) Emigration, remittances and labor force participation in Mexico. In: Working paper, no. 28, Inter-American Development Bank

Kim N (2007) The impact of remittances on labor supply: the case of Jamaica. In: World Bank policy research working paper, no. 4120. The World Bank, Bretton Woods

Medina C, Cardona L (2010) The effects of remittances on household consumption, education attendance and living standards: the case of Colombia. In: Lecturas de Economía, vol 72, Enero-Junio, pp 11-43

Medina C, Posso CM (2009) Colombian and South American immigrants in the United States of America: education levels, job qualifications and the decision to go back home. Borradores de Economía, vol 572, Banco de la República

Mora J (2013) Gender differences between remittances and labor participation in developing countries: a cross-section analysis of Colombia in year 2008. Appl Econ Int Dev 13-1:99-112

Sánchez RE (2008) Brief reviews of the relationship among emigration, poverty and overseas workers's remittances in Colombia. Rev Econ Adm 5(1):119-151 